\title{
Metal complexation of deferasirox derivatives: A solid state and equilibrium study
}

\author{
Imre Nagy ${ }^{a}$, Gergő Ferenczik ${ }^{a}$, Linda Bíróa ${ }^{a}$, Etelka Farkas ${ }^{a}$, Attila Cs. Bényei ${ }^{b}$, Péter Buglyó a,* \\ ${ }^{a}$ Department of Inorganic and Analytical Chemistry, University of Debrecen, Egyetem tér 1., H-4032 Debrecen, Hungary \\ ${ }^{\mathrm{b}}$ Department of Physical Chemistry, University of Debrecen, Egyetem tér 1., H-4032 Debrecen, Hungary
}

\section{A R T I C L E I N F O}

\section{Article history:}

Received 20 July 2020

Accepted 30 August 2020

Available online 6 September 2020

\section{Keywords:}

Deferasirox

Anticancer

Speciation

$\mathrm{Ru}, \mathrm{Os}, \mathrm{Co}$, Ga complexes

Single crystal structures

\begin{abstract}
A B S T R A C T
Complexation of deferasirox (4-[3,5-bis(2-hydroxyphenyl)-1,2,4-triazol-1-yl]benzoic acid, $\mathrm{H}_{3} \mathrm{~L}_{\mathrm{B}}$ ) and its decarboxy derivative $\left(\mathrm{H}_{2} \mathrm{~L}_{\mathrm{A}}\right)$ with $\mathrm{Ru}(\mathrm{III}), \mathrm{Os}(\mathrm{IV}), \mathrm{Co}(\mathrm{III})$ and $\mathrm{Ga}(\mathrm{III})$ was studied. These novel complexes with likely multitargeted capabilities are expected to show anticancer potential after biotransformation via both of the metal ion and the liberated ligand. Formation of $1: 2$ octahedral complexes with a $(\mathrm{O}, \mathrm{N}, \mathrm{O})$ tridentate coordination of the ligands was found yielding $\mathrm{K}_{3}\left[\mathrm{Ru}\left(\mathrm{L}_{\mathrm{B}}\right)_{2}\right], \mathrm{K}\left[\mathrm{Co}\left(\mathrm{L}_{\mathrm{A}}\right)_{2}\right], \mathrm{K}_{3}\left[\mathrm{Co}\left(\mathrm{L}_{\mathrm{B}}\right)_{2}\right]$ and (guanidinium $) \mathrm{Na}_{2}\left[\mathrm{Ga}\left(\mathrm{L}_{\mathrm{B}}\right)_{2}\right]$, respectively. The molecular structure obtained by single crystal X-ray diffraction also confirmed the octahedral geometry for $\mathrm{K}\left[\mathrm{Co}\left(\mathrm{L}_{\mathrm{A}}\right)_{2}\right] \cdot 2 \mathrm{Pr}^{\mathrm{i}} \mathrm{OH}$. Unprecedented formation of $\mathrm{K}_{2}\left[\mathrm{Os}^{\mathrm{VI}} \mathrm{L}_{\mathrm{B}}(\mathrm{O})_{2}(\mathrm{OH})\right]$ having a tridentate $(\mathrm{O}, \mathrm{N}, \mathrm{O})$ coordinating ligand, two oxo groups and a hydroxide ion in the coordination sphere of the metal ion with +6 oxidation state was also found. Simple synthesis and solid state structure of the novel disulfonated derivatives of $\mathrm{H}_{3} \mathrm{~L}_{\mathrm{B}}$, and $\mathrm{H}_{2} \mathrm{~L}_{\mathrm{A}}$, $\left(\mathrm{H}_{5} \mathrm{~L}_{\mathrm{D}}\right.$ and $\mathrm{H}_{4} \mathrm{~L}_{\mathrm{C}}$, respectively, with excellent water solubility) is also presented. Interaction of $\mathrm{Ga}$ (III) with $\mathrm{H}_{4} \mathrm{~L}_{\bar{D}}$ and $\mathrm{H}_{3} \mathrm{~L}_{\bar{C}}$ resulted in the formation of $1: 1$ and 1:2 complexes with different protonation degree in aqueous solution among them $\left[\mathrm{Ga}\left(\mathrm{L}_{\mathrm{D}}\right)_{2}\right]^{7-}$ and $\left[\mathrm{Ga}\left(\mathrm{L}_{\mathrm{C}}\right)_{2}\right]^{5-}$ being the major species under physiologically relevant conditions.
\end{abstract}

(ㄷ 2020 The Author(s). Published by Elsevier Ltd. This is an open access article under the CC BY license (http://creativecommons.org/licenses/by/4.0/).

\section{Introduction}

Three effective iron-chelating drugs are currently available for the treatment of iron overload diseases: the trishydroxamatebased hexadentate desferrioxamine $\mathrm{B}\left(\mathrm{H}_{3} \mathrm{DFB}\right)$, the bidentate 1,2 dimethyl-3-hydroxy-4(1H)-pyridinone (deferiprone, HDFP) and the tridentate 4-[3,5-bis(2-hydroxyphenyl)-1,2,4-triazol-1-yl]benzoic acid (deferasirox, $\mathrm{H}_{3} \mathrm{~L}_{\mathrm{B}}$ ). $\mathrm{H}_{3} \mathrm{DFB}$, has been extensively used for the past several decades, but its short biological half-life and oral inactivity prompted researchers for the development of new and orally active alternatives. Out of the synthesized numerous compounds, several have been evaluated for clinical use, but, according to the best of our knowledge, up to now, only two orally active drugs have been approved worldwide: HDFP (1999 - Europe, 2011 - FDA) and $\mathrm{H}_{3} \mathrm{~L}_{\mathrm{B}}$ (2005 - FDA) [1-6].

The direct correlation between the very effective iron-binding behaviour of $\mathrm{H}_{3} \mathrm{~L}_{B}$ and its above-mentioned importance in the treatment of iron overload diseases initiated studies in several laboratories regarding its metal complexation [7-10]. In addition to

\footnotetext{
* Corresponding author.

E-mail address: buglyo@science.unideb.hu (P. Buglyó).
}

iron, some other biorelevant metal ions ( $\mathrm{Ca}(\mathrm{II}), \mathrm{Mg}(\mathrm{II}), \mathrm{Cu}(\mathrm{II})$ and $\mathrm{Zn}(\mathrm{II})$ ), the toxic $\mathrm{Al}(\mathrm{III})$ and also $\mathrm{V}(\mathrm{IV})$ ) were involved in solid state, solution equilibrium and redox activity studies with $\mathrm{H}_{3} \mathrm{~L}_{B}$ and some derivatives by Hegetschweiler et al. [7-9]. Because the very limited water solubility of $\mathrm{H}_{3} \mathrm{~L}_{B}$ hindered the use of pure aqueous medium solution studies were carried out in a water/DMSO solvent mixture $\left(\mathrm{x}_{\mathrm{DMSO}}=0.20\right)$. The results clearly confirmed the tridentate $(O, N, O)$ coordination of the ligand in all cases, the very high stability of the iron- $\mathrm{L}_{\mathrm{B}}^{3-}$ complexes, the high selectivity of $\mathrm{H}_{3} \mathrm{~L}_{\mathrm{B}}$ for iron in the presence of the studied other biometals, and the possibility of sequestration of aluminium(III) by $\mathrm{H}_{3} \mathrm{~L}_{B}$ as well [7,8]. A biological study also supported the applicability of $\mathrm{H}_{3} \mathrm{~L}_{B}$ (first of all in combination with HDFP) for the removal of toxic lead(II) from the body [10]. Quantitative evaluation of the effects of iron(III) chelation on the physiological concentrations of essential metal ions like copper(II) and zinc(II) showed that these metal ions do not disturb iron(III) chelation by $\mathrm{H}_{3} \mathrm{~L}_{B}$ [11].

Due to the increased iron demand in cancer cells generated by the rapid DNA synthesis and growth compared to the normal cells, drugs, which are effective iron-sequestering agents, display antitumor potential as well. Therefore, inhibiting iron metabolism in cancer cells is a recently realized strategy for the treatment of cancer 
[12-14]. After the discovery of tumor growth inhibition by $\mathrm{H}_{3} \mathrm{~L}_{\mathrm{B}}$, this drug together with some derivatives have also gained great attention in cancer chemotherapy and have been tested against various cancer cell lines [15-17].

The tendency nowadays for creating multi-functional, multitargeted drug candidate molecules generates intensive interest towards metal complexes of drug chelators $[18,19]$. In this strategy metal complexes can especially be interesting in which both the metal ion and the ligand exhibit its own cytotoxic activity and none of them is merely a delivery component of the other one. This concept is well demonstrated by recent results obtained on the complex $\left[\mathrm{Ti}\left(\mathrm{L}_{\mathrm{B}}\right)_{2}\right]^{2-}$ prepared to develop a novel Ti(IV)-based anticancer drug. The results of this work supported the replacement of the chelated Ti(IV) by Fe(III), resulting in anticancer activity based on a dual action. In particular, activation of the cytotoxic Ti(IV) as a result of transmetallation and sequestration of $\mathrm{Fe}(\mathrm{III})$ with $\mathrm{H}_{3} \mathrm{~L}_{B}$ occur in the same process [20]. This idea initiated our work and based on our skills in this field [21-24], new metal complexes with the drug molecule, $\mathrm{H}_{3} \mathrm{~L}_{\mathrm{B}}$, with its decarboxy derivative and with two novel water soluble disulfonato derivatives have been synthesized and characterized (the structures of the ligands are shown in Fig. 1). Although the presence or absence of the carboxylate group does not play an important role in the metal ion binding capabilities of these molecules decarboxy deferasirox complexes may behave differently under biological conditions due to their altered lipophilicity, overall charge, size etc. therefore we have also involded this chelator and its new sulfonated derivative in the studies. Beside their bioactivity, these ligands are expected to deliver effectively the selected cytotoxic Ru(III) and Os(IV) $[25,26]$, as well as $\mathrm{Ga}$ (III) [27-29] with high tendency for hydrolysis, which are among the frequently used metal ions (beside platinum) to develop anticancer metallodrugs. The fourth metal ion, which has been involved in the present study, $\mathrm{Co}(\mathrm{III})$, is not stable in the form of $\left[\mathrm{Co}\left(\mathrm{H}_{2} \mathrm{O}\right)_{6}\right]^{3+}$, but $\mathrm{H}_{3} \mathrm{~L}_{\mathrm{B}}$-based chelators were believed to provide a platform for the formation of thermodynamically stable and kinetically inert $\mathrm{Co}$ (III) complexes. As it is known from previous results, activation of bifunctional moieties can also be achieved via reduction of the $\mathrm{Co}$ (III) complexes resulting in the formation of kinetically labile, thermodynamically not very stable, consequently dissociable Co(II) complexes [30].

The present paper is aimed to summarize our results mainly on the synthesis and chemical characterization of the complexes. Because of kinetic and solubility reasons, solution equilibrium study could only be carried out in the systems containing gallium(III) and the new water soluble disulphonate derivatives, $\mathrm{H}_{3} \mathrm{~L}_{\mathrm{C}}^{-}$and $\mathrm{H}_{4} \mathrm{~L}_{\mathrm{D}}^{-}$.

\section{Experimental}

\subsection{Materials and reagents}

$\mathrm{H}_{2} \mathrm{SO}_{4}, \mathrm{MeOH}$, acetone, $\mathrm{K}_{2} \mathrm{CO}_{3}, \mathrm{Ga}\left(\mathrm{NO}_{3}\right)_{3}, \mathrm{CsNO}_{3}$, guanidine nitrate, $\mathrm{RuCl}_{3}, \mathrm{Na}_{2} \mathrm{CO}_{3}\left(\mathrm{NH}_{4}\right)_{2} \mathrm{OsCl}_{6}$ and various solvents were commercial products from Merck, Sigma Aldrich, VWR, Reanal and used as received. $\mathrm{Co}(\mathrm{acac})_{3}$ (acac $=$ acetylacetonate) [31], 3,5-bis (2-hydroxyphenyl)-1-phenyl-1,2,4-triazole $\left(\mathrm{H}_{2} \mathrm{~L}_{\mathrm{A}}\right)$ and 4-[3,5-bis (2-hydroxyphenyl)-1,2,4-triazol-1-yl]benzoic acid $\left(\mathrm{H}_{3} \mathrm{~L}_{\mathrm{B}}\right)$ were prepared by the appropriate literature method [8].

\subsection{Synthesis of the new ligands and complexes}

\subsubsection{3,5-Bis(2-hydroxy-5-sulfophenyl)-1-phenyl-1,2,4-triazole $\left(H_{4} L_{C}\right)$}

$1.00 \mathrm{~g}$ ( $3.04 \mathrm{mmol}$ ) $\mathrm{H}_{2} \mathrm{~L}_{\mathrm{A}}$ was added to $4 \mathrm{~cm}^{3} \mathrm{cc} . \mathrm{H}_{2} \mathrm{SO}_{4}$ and the mixture was stirred at $130{ }^{\circ} \mathrm{C}$ for $3 \mathrm{hr}$. After cooling down $3 \mathrm{~cm}^{3}$ water was added and next day the white creamy solid was filtered off and recrystallized from water. The white product was filtered off and dried in vacuo. Yield: $0.561 \mathrm{~g}(30 \%)$. Single crystals were obtained via the slow evaporation of a $\mathrm{NaCl}$ containing aqueous solution of the product. ${ }^{1} \mathrm{H}$ NMR (400 MHz, DMSO): $8.32(\mathrm{~d}, 1 \mathrm{H}$, Ar-H); 7.77 (d, 1H, Ar-H); 7.59 (m, 2H, Ar-H); 7.45 (m, 5H, Ar-H); 6.99 (d, $1 \mathrm{H}, \mathrm{Ar}-\mathrm{H}) ; 6.85$ (d, $1 \mathrm{H}, \mathrm{Ar}-\mathrm{H})$. IR $(\mathrm{KBr}) / \mathrm{cm}^{-1}$ : 3395.07 , $1620.88,1416.46,1311.36,1171.54,1027.87,834.06,593.01$. MS<smiles></smiles><smiles></smiles>

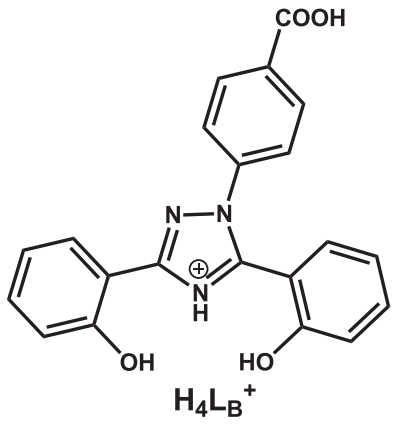

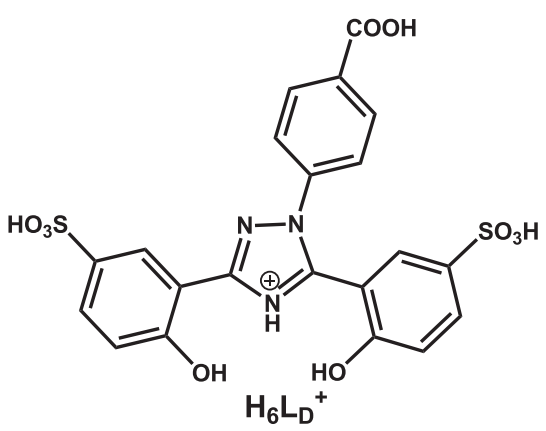

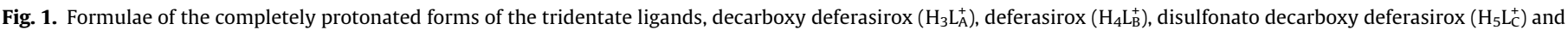

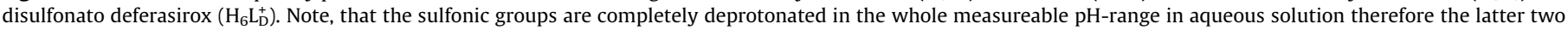
ligands will be abbreviated as $\mathrm{H}_{3} \mathrm{~L}_{\overline{\mathrm{C}}}^{-}$and $\mathrm{H}_{4} \mathrm{~L}_{\bar{D}}^{-}$throughout the text. 
(ESI, negative ion): $m / z: 243.5081\left(\mathrm{C}_{20} \mathrm{H}_{13} \mathrm{~N}_{3} \mathrm{O}_{8} \mathrm{~S}_{2}: 243.5078\right.$; $\left.\left[\mathrm{H}_{2} \mathrm{~L}_{\mathrm{C}}\right]^{2-}\right)$.

\subsubsection{4-[3,5-Bis(2-hydroxy-5-sulfophenyl)-1H-1,2,4-triazol-1-yl] benzoic acid $\left(H_{5} L_{D}\right)$}

$1.00 \mathrm{~g}$ ( $2.68 \mathrm{mmol}$ ) $\mathrm{H}_{3} \mathrm{~L}_{\mathrm{B}}$ was added to $4 \mathrm{~cm}^{3} \mathrm{cc}$. $\mathrm{H}_{2} \mathrm{SO}_{4}$. The mixture was stirred at $130{ }^{\circ} \mathrm{C}$ for $3 \mathrm{hr}$. After cooling down $3 \mathrm{~cm}^{3}$ water was added and next day the white creamy solid was filtered off and recrystallized from water. The product was filtered off and dried in vacuo. Yield: $0.472 \mathrm{~g}$ (27\%). Single crystals were obtained via the slow evaporation of a $\mathrm{NaCl}$ containing aqueous solution of the product. ${ }^{1} \mathrm{H}$ NMR (400 MHz, DMSO): $10.34(\mathrm{~s}, 1 \mathrm{H}, \mathrm{OH}) ; 8.34$ (d, $1 \mathrm{H}, \mathrm{Ar}-\mathrm{H}) ; 8.01$ (d, 2H, Ar-H); 7.84 (d, 1H, Ar-H); 7.60 (m, 4H, Ar$\mathrm{H}) ; 6.99$ (d, $1 \mathrm{H}, \mathrm{Ar}-\mathrm{H}) ; 6.83$ (d, $1 \mathrm{H}, \mathrm{Ar}-\mathrm{H})$. IR $(\mathrm{KBr}) / \mathrm{cm}^{-1}: 3420.14$, $1720.19,1616.06,1294.97,1226.5,1166.72,1031.73,832.13$, 674.96, 591.08. MS (ESI, negative ion): $m / z: 265.5024\left(\mathrm{C}_{21} \mathrm{H}_{13} \mathrm{~N}_{3^{-}}\right.$ $\mathrm{O}_{10} \mathrm{~S}_{2}: 265.5027 ;\left[\mathrm{H}_{3} \mathrm{~L}_{\mathrm{D}}\right]^{2-}$ ).

\subsection{3. $K_{3}\left[R u\left(L_{B}\right)_{2}\right]$}

$0.60 \mathrm{~g}$ (1.61 mmol) $\mathrm{H}_{3} \mathrm{~L}_{\mathrm{B}}$ and $0.167 \mathrm{~g}$ (0.801 $\left.\mathrm{mmol}\right) \mathrm{RuCl}_{3}$ were dissolved in $180 \mathrm{~cm}^{3}$ of $\mathrm{MeOH}, 3.36 \mathrm{~g}$ (24.15 mmol) $\mathrm{K}_{2} \mathrm{CO}_{3}$ was added and the reaction mixture was refluxed for $24 \mathrm{~h}$. The mixture was brought to dryness in rotavapor and redissolved in $30 \mathrm{~cm}^{3}$ water. On standing at room temperature black paste-like solid was obtained. The solid was filtered off and dried in vacuo. Yield: $0.298 \mathrm{~g}$ (42\%). ${ }^{1} \mathrm{H}$ NMR (400 MHz, DMSO): 8.01 (d, 2H, Ar-H); 7.82 (d, 4H, Ar-H); 7.42 (d, 4H, Ar-H); 7.32 (t, 2H, Ar-H); 7.11 (m, $2 \mathrm{H}, \mathrm{Ar}-\mathrm{H}) ; 7.05$ (t, 2H, Ar-H); 6.98 (m, 4H, Ar-H); 6.37 (d, 4H, ArH). IR (KBr) $/ \mathrm{cm}^{-1}$ : 3397.96, 3197.4, 2310.3, 1601.59, 1455.99, 1377.89, 882.27, 704.86. MS (ESI, negative ion): $\mathrm{m} / \mathrm{z}: 421.5400$ $\left(\mathrm{C}_{42} \mathrm{H}_{25} \mathrm{~N}_{6} \mathrm{O}_{8} \mathrm{Ru}: 421.5400\right.$; $\left.\left[\mathrm{Ru}\left(\mathrm{L}_{\mathrm{B}}\right)_{2}+\mathrm{H}\right]^{2-}\right), 844.0871\left(\mathrm{C}_{42} \mathrm{H}_{26} \mathrm{~N}_{6^{-}}\right.$ $\mathrm{O}_{8} \mathrm{Ru}$ : 844.0873; $\left.\left[\mathrm{Ru}\left(\mathrm{L}_{\mathrm{B}}\right)_{2}\right]^{3-}\right)$. Anal. required for $\mathrm{C}_{42} \mathrm{H}_{24} \mathrm{~N}_{6} \mathrm{O}_{8} \mathrm{RuK}_{3}$ : C, 52.60, H, 2.52, N, 8.76\%. Found: C, 52.31, H, 2.68, N, 8.67\%.

\subsection{4. $\mathrm{K}\left[\mathrm{Co}\left(L_{A}\right)_{2}\right]$}

$0.30 \mathrm{~g}(0.917 \mathrm{mmol}) \mathrm{H}_{2} \mathrm{~L}_{\mathrm{A}}$ and $0.163 \mathrm{~g}(0.454 \mathrm{mmol}) \mathrm{Co}(\mathrm{acac})_{3}$ were dissolved in $20 \mathrm{~cm}^{3} \mathrm{MeOH}, 3.76 \mathrm{~g}$ (27.51 mmol) $\mathrm{K}_{2} \mathrm{CO}_{3}$ was added and the reaction mixture was refluxed for $6 \mathrm{~h}$. It was brought to dryness in rotavapor and dissolved in acetone. The insoluble $\mathrm{K}_{2} \mathrm{CO}_{3}$ was filtered off. Slow evaporation of the brown solution gave a brown solid. The microcrystalline product was filtered off and dried in vacuo. Yield: $0.154 \mathrm{~g}(45 \%) .{ }^{1} \mathrm{H}$ NMR (400 MHz, DMSO): 7.83 (d, 2H, Ar-H); 7.74 (m, 10H, Ar-H); 6.74 $(\mathrm{d}, 2 \mathrm{H}, \mathrm{Ar}-\mathrm{H}) ; 6.62(\mathrm{t}, 2 \mathrm{H}, \mathrm{Ar}-\mathrm{H}) ; 6.56(\mathrm{t}, 2 \mathrm{H}, \mathrm{Ar}-\mathrm{H}) ; 6.37(\mathrm{t}, 2 \mathrm{H}$, $\mathrm{Ar}-\mathrm{H}) ; 6.1(\mathrm{~m}, 6 \mathrm{H}, \mathrm{Ar}-\mathrm{H})$. IR $(\mathrm{KBr}) / \mathrm{cm}^{-1}$ : 3397.96, 3052.76, 2570.65, 1895.68, 1560.13, 1475.28, 1266.04, 981.59, 755.96. MS (ESI, negative ion): $m / z$ : $713.1356\left(\mathrm{C}_{40} \mathrm{H}_{26} \mathrm{~N}_{6} \mathrm{O}_{8} \mathrm{Co}\right.$ : 713.1353; [Co $\left.\left(\mathrm{L}_{\mathrm{A}}\right)_{2}\right]^{-}$). Anal. required for $\mathrm{C}_{40} \mathrm{H}_{26} \mathrm{CoN}_{6} \mathrm{O}_{4} \mathrm{~K}: \mathrm{C}, 63.83, \mathrm{H}, 3.48 \mathrm{~N}$, $11.17 \%$ Found: C, 63.48, H, 3.65, N, $11.02 \%$.

\subsection{5. $\mathrm{K}_{3}\left[\mathrm{Co}\left(L_{B}\right)_{2}\right]$}

$0.30 \mathrm{~g}$ (0.804 mmol) $\mathrm{H}_{3} \mathrm{~L}_{\mathrm{B}}$ and $0.143 \mathrm{~g}(0.402 \mathrm{mmol}) \mathrm{Co}(\mathrm{acac})_{3}$ were dissolved in $20 \mathrm{~cm}^{3} \mathrm{MeOH}, 3.33 \mathrm{~g}$ (24.12 mmol) $\mathrm{K}_{2} \mathrm{CO}_{3}$ was added and the reaction mixture was refluxed for $6 \mathrm{~h}$. It was brought to dryness in rotavapor and the obtained solid was dissolved in $15 \mathrm{~cm}^{3}$ water. On standing at room temperature a black solid was obtained. The product was filtered off and dried in vacuo. Yield: $0.119 \mathrm{~g}$ (37\%). ${ }^{1} \mathrm{H}$ NMR (400 MHz, DMSO): 8.12 (d, 4H, Ar-H); $7.83(\mathrm{~d}, 2 \mathrm{H}, \mathrm{Ar}-\mathrm{H}) ; 7.61$ (d, 4H, Ar-H); 6.76 (d, 2H, Ar-H); 6.61 (t, 2H, Ar-H); 6.55 (t, 2H, Ar-H); $6.36(\mathrm{t}, 2 \mathrm{H}, \mathrm{Ar}-\mathrm{H}) ; 6.10(\mathrm{~m}, 6 \mathrm{H}$, $\mathrm{Ar}-\mathrm{H})$. IR $(\mathrm{KBr}) / \mathrm{cm}^{-1}:$ 3384.46, 1601.59, 1561.09, 1381.75, 1146.47, 981.59, 847.56, 757.89. MS (ESI, negative ion): $\mathrm{m} / \mathrm{z}$ : $801.1158\left(\mathrm{C}_{42} \mathrm{H}_{26} \mathrm{~N}_{6} \mathrm{O}_{8} \mathrm{Co}\right.$ : 801.1150; $\left.\left[\mathrm{Co}\left(\mathrm{L}_{\mathrm{B}}\right)_{2}+2 \mathrm{H}\right]{ }^{-}\right), 400.0545$ $\left(\mathrm{C}_{42} \mathrm{H}_{25} \mathrm{~N}_{6} \mathrm{O}_{8} \mathrm{Co}\right.$ : 400.0538; $\left.\left[\mathrm{Co}\left(\mathrm{L}_{\mathrm{B}}\right)_{2}+\mathrm{H}\right]^{2-}\right)$. Anal. required for $\mathrm{C}_{42} \mathrm{H}_{24} \mathrm{~N}_{6} \mathrm{O}_{8} \mathrm{CoK}_{3}$ : C, 55.02, H, 2.64, N, 9.17\%. Found: C, 54.81, H, $2.90, \mathrm{~N}, 9.27 \%$.

\subsection{6. (guanidinium) $\mathrm{Na}_{2}\left[\mathrm{Ga}\left(\mathrm{L}_{\mathrm{B}}\right)_{2}\right]$}

$0.50 \mathrm{~g}(1.34 \mathrm{mmol}) \mathrm{H}_{3} \mathrm{~L}_{\mathrm{B}}$ and $0.171 \mathrm{~g}(0.67 \mathrm{mmol})$ of $\mathrm{Ga}\left(\mathrm{NO}_{3}\right)_{3}$ were added to the mixture of $30 \mathrm{~cm}^{3}$ of $\mathrm{H}_{2} \mathrm{O}$ and $120 \mathrm{~cm}^{3}$ of $\mathrm{MeOH}$. To the opalescent reaction mixture altogether $0.30 \mathrm{~g}(2.83 \mathrm{mmol})$ $\mathrm{Na}_{2} \mathrm{CO}_{3}$ was added during $8 \mathrm{~h}$ in $0.03 \mathrm{~g}$ portions to adjust the $\mathrm{pH}$ to 8.0. After addition the reaction mixture was refluxed for $16 \mathrm{~h}$, it was brought to dryness in rotavapor and the obtained solid was disssolved in $20 \mathrm{~cm}^{3}$ water. To this solution $0.082 \mathrm{~g}$ $(0.67 \mathrm{mmol})$ guanidine nitrate was added and the volume of the solution was reduced to $5 \mathrm{~cm}^{3}$. At $4{ }^{\circ} \mathrm{C}$ white crystals appeared. The solid was filtered off and washed with $50 \mathrm{~cm}^{3}$ acetone. The product was dried in vacuo. Yield: $0.336 \mathrm{~g}$ (58\%). ${ }^{1} \mathrm{H}$ NMR (400 MHz, DMSO): 8.11 (d, 4H, Ar-H); 7.86 (s, 6H, NH); 7.81 (d, $2 \mathrm{H}, \mathrm{Ar}-\mathrm{H}) ; 7.58$ (d, $4 \mathrm{H}, \mathrm{Ar}-\mathrm{H}) ; 6.85(\mathrm{t}, 2 \mathrm{H}, \mathrm{Ar}-\mathrm{H}) ; 6.78(\mathrm{t}, 2 \mathrm{H}, \mathrm{Ar}-$ $\mathrm{H}) ; 6.71(\mathrm{~d}, 2 \mathrm{H}, \mathrm{Ar}-\mathrm{H}) ; 6.42(\mathrm{t}, 2 \mathrm{H}, \mathrm{Ar}-\mathrm{H}) ; 6.15(\mathrm{t}, 2 \mathrm{H}, \mathrm{Ar}-\mathrm{H}) ; 6.04$ (t, 4H, Ar-H). IR (KBr)/cm ${ }^{-1}: 3420.14,2371.05,1604.48,1461.78$, 1261.22, 841.78, 759.82. MS (ESI, negative ion): $m / z: 405.0494$ $\left(\mathrm{C}_{42} \mathrm{H}_{25} \mathrm{~N}_{6} \mathrm{O}_{8} \mathrm{Ga}\right.$ : 405.0500; $\left.\left[\mathrm{Ga}\left(\mathrm{L}_{\mathrm{B}}\right)_{2}+\mathrm{H}\right]^{2-}\right), 811.1078\left(\mathrm{C}_{42} \mathrm{H}_{26} \mathrm{~N}_{6}-\right.$ $\mathrm{O}_{8} \mathrm{Ga}$ : 811.1073; $\left.\left[\mathrm{Ga}\left(\mathrm{L}_{\mathrm{B}}\right)_{2}+2 \mathrm{H}\right]^{-}\right)$. Anal. required for $\mathrm{C}_{43} \mathrm{H}_{30} \mathrm{~N}_{9} \mathrm{O}_{8^{-}}$ $\mathrm{GaNa}_{2}$ : C, 56.35, H, 3.30, N, 13.76\%. Found: C, 55.98, H, 3.48, N, $13.54 \%$.

\subsection{NMR, IR and ESI-MS measurements}

The NMR measurements were carried out using a Bruker DRX 400 NMR spectrometer at room temperature on samples prepared in $\mathrm{d}^{6}$-DMSO. Calibration was performed using the signal of the solvent, $2.50 \mathrm{ppm}$ for DMSO. IR spectra as $\mathrm{KBr}$ pellets were recorded on a Perkin Elmer FTIR Paragon 1000 PC instrument at the Department of Organic Chemistry, University of Debrecen. ESI-TOF MS measurements in the negative mode were carried out on a Bruker micrOTOF-Q type Qq-TOF-MS instrument, Bruker Daltonik, Bremen Germany, at the Department of Inorganic and Analytical Chemistry, University of Debrecen. The concentration of the samples was $10 \mu \mathrm{g} / \mathrm{mL}$ and the solvent was methanol. The instrument was equipped with an electrospray ion source, where the voltage was $4 \mathrm{kV}$. The drying gas was $\mathrm{N}_{2}$. The flow rate was $4.0 \mathrm{~mL} / \mathrm{min}$ and the drying temperature was $200{ }^{\circ} \mathrm{C}$. The spectra were recorded by means of a digitizer at a sampling rate of $2 \mathrm{GHz}$. The instrument was calibrated externally, using the exact masses of clusters $\left[(\mathrm{HCOONa})_{n}+\mathrm{Na}\right]^{+}$generated from the electrosprayed solution of sodium-formate. The spectra were evaluated with DataAnalysis 4.4 software from Bruker. The samples were introduced directly into the ESI with a syringe pump.

\subsection{Solution studies: pH-potentiometry, NMR titration}

For the gallium(III) systems pH-potentiometric titrations with $\mathrm{H}_{4} \mathrm{~L}_{\mathrm{C}}$ and $\mathrm{H}_{5} \mathrm{~L}_{\mathrm{D}}$ were carried out at $25.0^{\circ} \mathrm{C}$ in the presence of $0.20 \mathrm{M} \mathrm{KCl}$ ionic strength. Carbonate free, ca. $0.2 \mathrm{M} \mathrm{KOH}$ solution of known concentration was used as titrant. The exact concentration of the $\mathrm{HCl}$ and $\mathrm{KOH}$ solutions were determined by $\mathrm{pH}$-metric titrations using Gran's method. [32] A Mettler Toledo DL50 titrator equipped with a Mettler Toledo DGi 114-SC combined glass electrode was used for the titrations. The electrode system was calibrated according to Irving et al. [33] The water ionization constant was $\mathrm{pK}_{\mathrm{w}}=13.76 \pm 0.01$ under the applied experimental conditions. The initial volume of the samples was $15.00 \mathrm{~mL}$, the ligand concentrations were varied in the range of $1.79-2.02 \mathrm{mM}$, the metal ion to ligand ratios were $1: 2$ and $1: 1$, the samples were stirred and completely deoxygenized by bubbling purified argon. The titrations were performed in the range of $\mathrm{pH}=2.0-11.0$ in equilibrium-controlled mode, where the $\mathrm{pH}$ equilibrium was assumed to be reached if a change in the measured potential 
was $<0.01 \mathrm{mV}$ within $11 \mathrm{~s}$. The maximum waiting time in each titration point was $15 \mathrm{~min}$.

The overall stability constants of the complexes were calculated using the following equation:

$\beta_{\mathrm{pqr}}=\left[\mathrm{Ga}_{\mathrm{p}} \mathrm{H}_{\mathrm{q}} \mathrm{L}_{\mathrm{r}}\right] /[\mathrm{Ga}]^{\mathrm{p}}[H]^{\mathrm{q}}[\mathrm{L}]^{\mathrm{r}}$

where "L" represents the completely deprotonated forms of the ligands.

The protonation constants of the ligands, and the stability constants of the complexes were calculated with the aid of the SUPERQUAD [34] and PSEQUAD [35] computer programs, respectively. The stability constants of the Ga(III) hydroxido complexes $\left(\log \beta_{1}=-2.46, \log \beta_{2}=-5.92, \log \beta_{3}=-10.63\right.$ and $\log \beta_{4}=-16.87$ for the species $[\mathrm{Ga}(\mathrm{OH})]^{2+},\left[\mathrm{Ga}(\mathrm{OH})_{2}\right]^{+},\left[\mathrm{Ga}(\mathrm{OH})_{3}\right]$ and $\left[\mathrm{Ga}(\mathrm{OH})_{4}\right]{ }^{-}$, respectively) were taken from the literature. [36] These fixed values were involved in the equilibrium models during the calculations. A negative stoichiometric number for $\mathrm{H}$ in the formulae of the $\mathrm{Ga}$ (III) complexes indicates a proton, which dissociates only from the complex but neither from the ligand nor from the metal aqua ion separately and refers to mixed hydroxido complex formation.

${ }^{1} \mathrm{H}$ NMR titrations were carried out on a Bruker Avance 400 instrument at $25^{\circ} \mathrm{C}$ in the presence of $0.20 \mathrm{M} \mathrm{KCl}$. The chemical shifts $\left(\delta_{\mathrm{H}}\right)$ are reported in ppm from TSP as an internal standard. The samples were prepared in water/ $\mathrm{D}_{2} \mathrm{O} 9: 1$, the ligand concentration was $5.0 \mathrm{mM}$, the $\mathrm{Ga}(\mathrm{III})$ to ligand ratio was $1: 2$. $\mathrm{pH}$ of the samples were set up with $\mathrm{DNO}_{3}$ and $\mathrm{NaOD}$ solutions. The $\mathrm{pH}^{*}$ values (direct $\mathrm{pH}$-meter readings in $\mathrm{D}_{2} \mathrm{O}$ of a $\mathrm{pH}$-meter calibrated in $\mathrm{H}_{2} \mathrm{O}$ according to Irving et al. [33]) were converted to $\mathrm{pH}$ values according to the following equation: $\mathrm{pH}=0.936 \mathrm{pH}^{*}+0.412$ [37].

\subsection{Crystal structure analysis}

X-ray quality crystals were grown by slow evaporation of the solutions. A suitable crystal was fixed under microscope onto a Mitegen loop using high density oil. Diffraction intensity data collection was carried out using a Bruker-D8 Venture diffractometer equipped with INCOATEC I $\mu$ S 3.0 dual ( $\mathrm{Cu}$ and Mo) sealed tube micro sources and Photon II Charge-Integrating Pixel Array detector using Mo $\mathrm{K} \alpha(\lambda=0.71073 \AA)$ radiation. Low temperature data collection $(100 \mathrm{~K})$ was applied in case of $\mathrm{K}\left[\mathrm{Co}\left(\mathrm{L}_{\mathrm{A}}\right)_{2}\right] \cdot 2 \mathrm{Pr}^{\mathrm{i}} \mathrm{OH}$ while the other structures could be determined using room temperature data collection. High multiplicity data collection and integration was performed using the APEX3 (Ver. 2017.3-0, Bruker AXS Inc., 2017.) software. Data reduction and multi-scan absorption correction was performed using SAINT (Ver. 8.38A, Bruker AXS Inc., 2017). The structure could be solved using direct methods and refined on F2 using the SHELXL program [38] incorporated into APEX3 suite. Refinement was performed anisotropically for all non-hydrogen atoms. Hydrogen atoms were placed into geometric positions except $\mathrm{N}-\mathrm{H}$ and $\mathrm{O}-\mathrm{H}$ protons which were located on the difference electron density map and the $\mathrm{N}-\mathrm{H}$ or $\mathrm{O}-\mathrm{H}$ distances were constrained. The CIF file was merged and manually edited using the Publcif software. [39] Results of X-ray diffraction structure determinations were very good according to the Checkcif of PLATON software [40] and structural parameters such as bond length and angle data are in the expected range. However, shift of water molecules caused several A level errors but this is not influencing the correctness of the structures. The crystallographic and refinement details can be seen in Table 1. CCDC 2016327-2016330 contain the supplementary crystallographic data for $\mathrm{H}_{3} \mathrm{~L}_{\mathrm{C}}, \mathrm{H}_{4} \mathrm{~L}_{\mathrm{D}}, \mathrm{K}_{2}\left[\mathrm{OsL}_{\mathrm{B}}(\mathrm{O})_{2}(\mathrm{OH})\right] \cdot 4 \mathrm{H}_{2} \mathrm{O}$ and $\mathrm{K}\left[\mathrm{Co}\left(\mathrm{L}_{\mathrm{A}}\right)_{2}\right] \cdot 2 \mathrm{Pr}^{\mathrm{i} O H}$, respectively. These data can be obtained free of charge from The

Table 1

Crystallographic parameters and refinement details for $\mathrm{NaH}_{3} \mathrm{~L}_{\mathrm{C}} \cdot 4 \mathrm{H}_{2} \mathrm{O}, \mathrm{NaH}_{4} \mathrm{~L}_{\mathrm{D}} \cdot 3.25 \mathrm{H}_{2} \mathrm{O}, \mathrm{K}_{2}\left[\mathrm{OsL}_{\mathrm{B}}(\mathrm{O})_{2}(\mathrm{OH})\right] \cdot 4 \mathrm{H}_{2} \mathrm{O}$ and $\mathrm{K}\left[\mathrm{Co}\left(\mathrm{L}_{\mathrm{A}}\right)_{2}\right] \cdot 2 \mathrm{Pr}^{\mathrm{i}} \mathrm{OH}$.

\begin{tabular}{|c|c|c|c|c|}
\hline & $\mathrm{NaH}_{3} \mathrm{~L}_{\mathrm{C}} \cdot 4 \mathrm{H}_{2} \mathrm{O}$ & $\mathrm{NaH}_{4} \mathrm{~L}_{\mathrm{D}} \cdot 3.25 \mathrm{H}_{2} \mathrm{O}$ & $\mathrm{K}_{2}\left[\mathrm{OsL}_{\mathrm{B}}(\mathrm{O})_{2}(\mathrm{OH})\right] \cdot 4 \mathrm{H}_{2} \mathrm{O}$ & $\mathrm{K}\left[\mathrm{Co}\left(\mathrm{L}_{\mathrm{A}}\right)_{2}\right] \cdot 2 \operatorname{Pr}^{\mathrm{i}} \mathrm{OH}$ \\
\hline \multicolumn{5}{|l|}{ Crystal data } \\
\hline Chemical formula & $\begin{array}{l}2\left(\mathrm{C}_{40} \mathrm{H}_{35} \mathrm{O}_{19.5} \mathrm{~N}_{6} \mathrm{Na}_{2} \mathrm{~S}_{4}\right) \cdot 8 \\
\left(\mathrm{H}_{2} \mathrm{O}\right)\end{array}$ & $\mathrm{C}_{42} \mathrm{H}_{40.50} \mathrm{~N}_{6} \mathrm{Na}_{2} \mathrm{O}_{26.50} \mathrm{~S}_{4}$ & $\mathrm{C}_{21} \mathrm{H}_{13} \mathrm{~K}_{2} \mathrm{~N}_{3} \mathrm{O}_{7} \mathrm{Os} \cdot 4 \mathrm{H}_{2} \mathrm{O}$ & $\mathrm{C}_{46} \mathrm{H}_{42} \mathrm{CoKN}_{6} \mathrm{O}_{6}$ \\
\hline$M_{\mathrm{r}}$ & 2316.04 & 1227.52 & 759.81 & 872.88 \\
\hline Crystal system, space group & Orthorhombic, Ccca & Monoclinic, $C 2 / c$ & Monoclinic, $P 2_{1} / c$ & Triclinic, $P 1$ \\
\hline Temperature $(\mathrm{K})$ & 293 & 298 & 298 & 100 \\
\hline$a, b, c(\AA)$ & $\begin{array}{l}11.9268(5), 32.7194(15) \\
26.4120(11)\end{array}$ & $\begin{array}{l}28.539(4), 13.6312(15) \\
30.464(4)\end{array}$ & $\begin{array}{l}14.284(2), 11.3048(14) \\
16.958(2)\end{array}$ & $\begin{array}{l}13.4918(9), 13.6315(10), \\
14.584(1)\end{array}$ \\
\hline$\alpha, \beta, \gamma\left({ }^{\circ}\right)$ & $90,90,90$ & $90,115.411$ (11), 90 & 90, 113.638 (9), 90 & $\begin{array}{l}63.496(2), 76.297(2) \\
63.198(2)\end{array}$ \\
\hline$V\left(\AA^{3}\right)$ & $10307.0(8)$ & $10,705(2)$ & $2508.6(6)$ & $2140.3(3)$ \\
\hline$Z$ & 4 & 8 & 4 & 2 \\
\hline Radiation type & Mo $K \alpha$ & $\mathrm{Cu} \mathrm{K} \alpha$ & Mo $K \alpha$ & Mo $K \alpha$ \\
\hline$\mu\left(\mathrm{mm}^{-1}\right)$ & 0.29 & 2.62 & 5.48 & 0.55 \\
\hline Crystal size $(\mathrm{mm})$ & $0.47 \times 0.25 \times 0.06$ & $0.50 \times 0.10 \times 0.05$ & $0.57 \times 0.17 \times 0.06$ & $0.44 \times 0.12 \times 0.10$ \\
\hline \multicolumn{5}{|l|}{ Data collection } \\
\hline Diffractometer & \multicolumn{4}{|l|}{ Bruker D8 VENTURE } \\
\hline Absorption correction & \multicolumn{4}{|c|}{ Multi-scan SADABS2016/2 - Bruker AXS area detector scaling and absorption correction } \\
\hline$T_{\min }, T_{\max }$ & $0.83,0.98$ & $0.72,0.88$ & $0.48,0.73$ & $0.77,0.95$ \\
\hline $\begin{array}{l}\text { No. of measured, independent and observed } \\
\quad[I>2 \sigma(I)] \text { reflections }\end{array}$ & $80420,4902,3455$ & $37439,10079,6970$ & $36656,5133,3154$ & $81631,7991,5672$ \\
\hline$R_{\text {int }}$ & 0.088 & 0.052 & 0.148 & 0.134 \\
\hline$(\sin \theta / \lambda)_{\max }\left(\AA^{-1}\right)$ & 0.611 & 0.610 & 0.626 & 0.607 \\
\hline \multicolumn{5}{|l|}{ Refinement } \\
\hline$R\left[F^{2}>2 \sigma\left(F^{2}\right)\right], \mathrm{w} R\left(F^{2}\right), S$ & $0.099,0.302,1.13$ & $0.124,0.248,4.01$ & $0.073,0.234,1.06$ & $0.068,0.214,1.11$ \\
\hline No. of reflections & 4902 & 10,079 & 5133 & 7991 \\
\hline No. of parameters & 376 & 796 & 374 & 555 \\
\hline No. of restraints & 16 & 27 & 25 & 3 \\
\hline \multirow[t]{3}{*}{$\mathrm{H}$-atom treatment } & \multicolumn{4}{|c|}{$\mathrm{H}$ atoms treated by a mixture of independent and constrained refinement } \\
\hline & $w=1 /\left[^{2}\left(F_{0}^{2}\right)+\right.$ & $w=1 /\left[\sigma^{2}\left(F_{\mathrm{o}}^{2}\right)+\right.$ & $w=1 /\left[\sigma^{2}\left(F_{\mathrm{o}}^{2}\right)+\right.$ & $w=1 /\left[\sigma^{2}\left(F_{\mathrm{o}}^{2}\right)+\right.$ \\
\hline & $\begin{array}{l}\left.(0.1597 P)^{2}+31.7114 P\right] \\
\text { where } P=\left(F^{2}+2 F^{2}\right) / 3\end{array}$ & $\left.(0.0012 P)^{2}+1.3012 P\right]$ & $\left.(0.1066 P)^{2}+28.2391 P\right]$ & $\left.(0.0773 P)^{2}+10.1866 P\right]$ \\
\hline$(\Delta / \sigma)_{\max }$ & 7.500 & $\begin{array}{l}\text { where } P=\left(F_{\mathrm{o}}^{2}+2 F_{\mathrm{c}}^{2}\right) / 3 \\
8.113\end{array}$ & $\begin{array}{l}\text { where } P=\left(F_{\mathrm{o}}^{2}+2 F_{\mathrm{c}}^{2}\right) / 3 \\
2.089\end{array}$ & $\begin{array}{l}\text { where } P=\left(F_{\mathrm{o}}^{2}+2 F_{\mathrm{c}}^{2}\right) / 3 \\
<0.001\end{array}$ \\
\hline$\Delta_{\max }, \Delta_{\min }\left(\mathrm{e} \AA^{-3}\right)$ & $1.13,-0.53$ & $1.46,-0.86$ & $2.48,-1.65$ & $2.10,-0.64$ \\
\hline
\end{tabular}




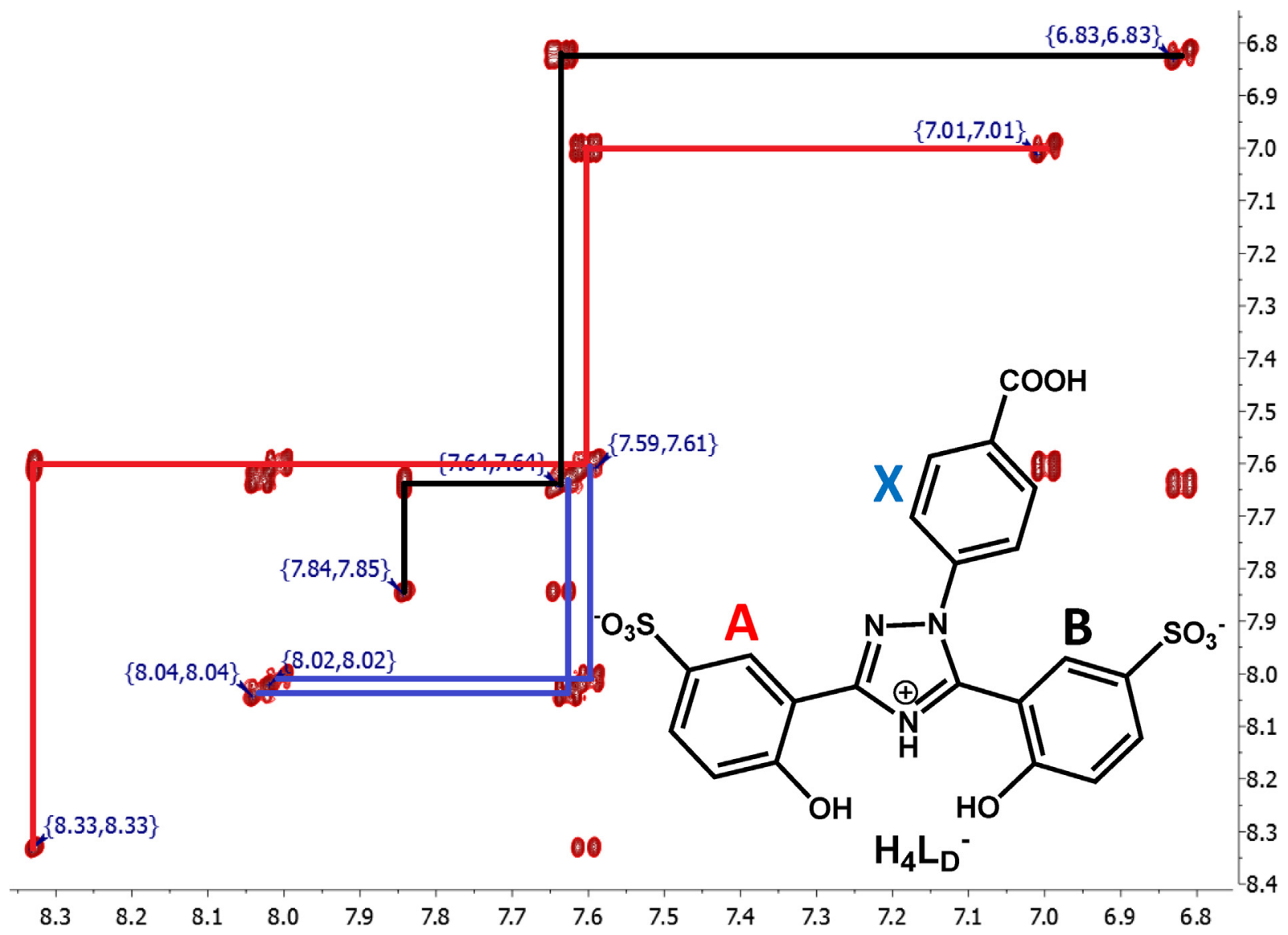

Fig. 2. Aromatic region of the COSY spectrum of $\mathrm{H}_{4} \mathrm{~L}_{\mathrm{D}}^{-}$in $\mathrm{d}^{6}$-DMSO; the three spin systems are indicated by different colors.

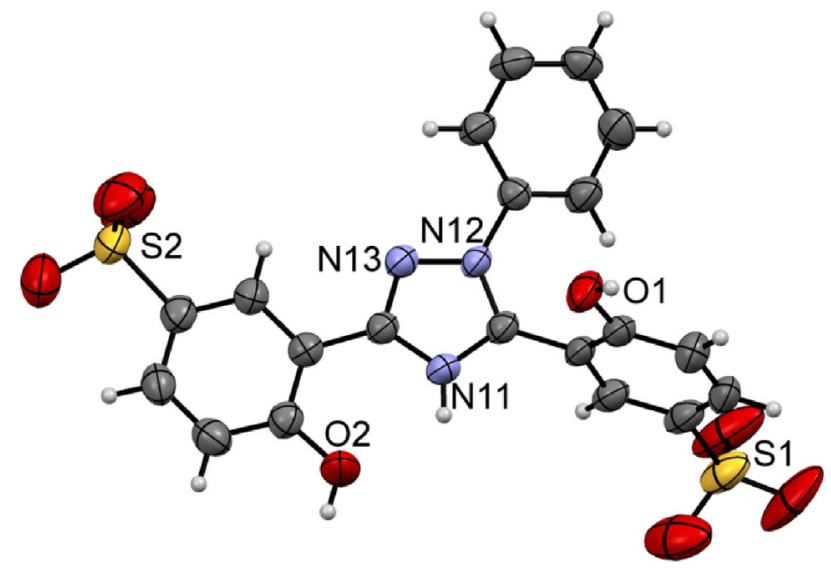

Fig. 3. ORTEP view of $\mathrm{H}_{3} \mathrm{~L}_{\overline{\mathrm{C}}}$. Thermal ellipsoids shown at $50 \%$ probability level with partial numbering scheme. The counter ion and water molecules are omitted for clarity.

Cambridge Crystallographic Data Centre via www.ccdc.cam.ac. uk/data_request/cif.

\section{Results and discussion}

\subsection{Synthesis and characterization of the ligands}

$\mathrm{H}_{2} \mathrm{~L}_{\mathrm{A}}$ and $\mathrm{H}_{3} \mathrm{~L}_{\mathrm{B}}$ were prepared by the appropriate literature method [8]. Since the solubility of these ligands in water is very

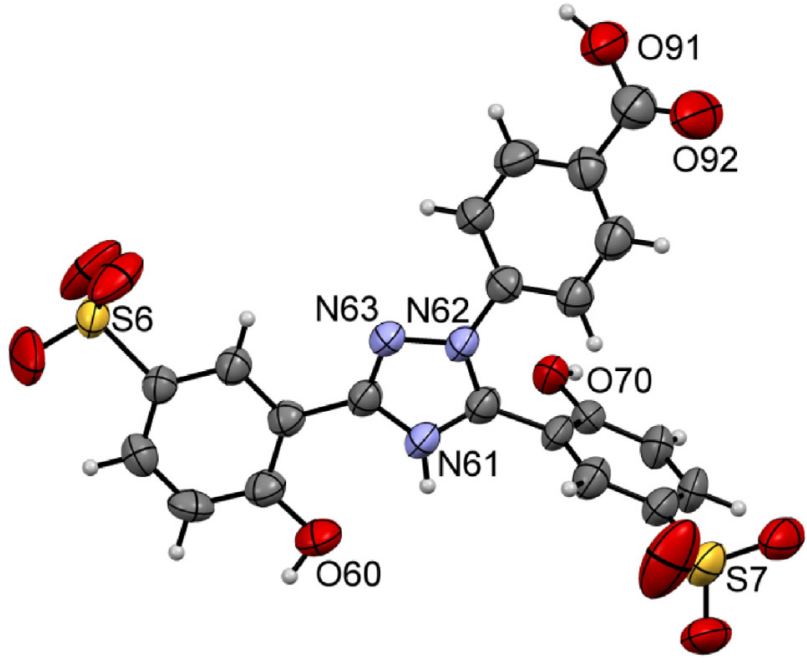

Fig. 4. ORTEP view of $\mathrm{H}_{4} \mathrm{~L}_{\mathrm{D}}^{-}$. Thermal ellipsoids shown at $50 \%$ probability level with partial numbering scheme. The counter ion and water molecules are omitted for clarity.

poor it hinders the equilibrium studies in aqueous medium but it can be increased via sulfonation. In a previous approach sulfonyl decorated 4-hydrazino-benzoic acid derivatives were first prepared and used to obtain 2-[3,5-bis(2-hydroxyphenyl)-1H-1,2,4triazol-1-yl]-benzene-1,4-disulfonic acid [41].

Our synthetic strategy for obtaining the new $\mathrm{H}_{4} \mathrm{~L}_{C}$ and $\mathrm{H}_{5} \mathrm{~L}_{D}$ ligands was different and involved the direct sulfonation of $\mathrm{H}_{2} \mathrm{~L}_{\mathrm{A}}$ 


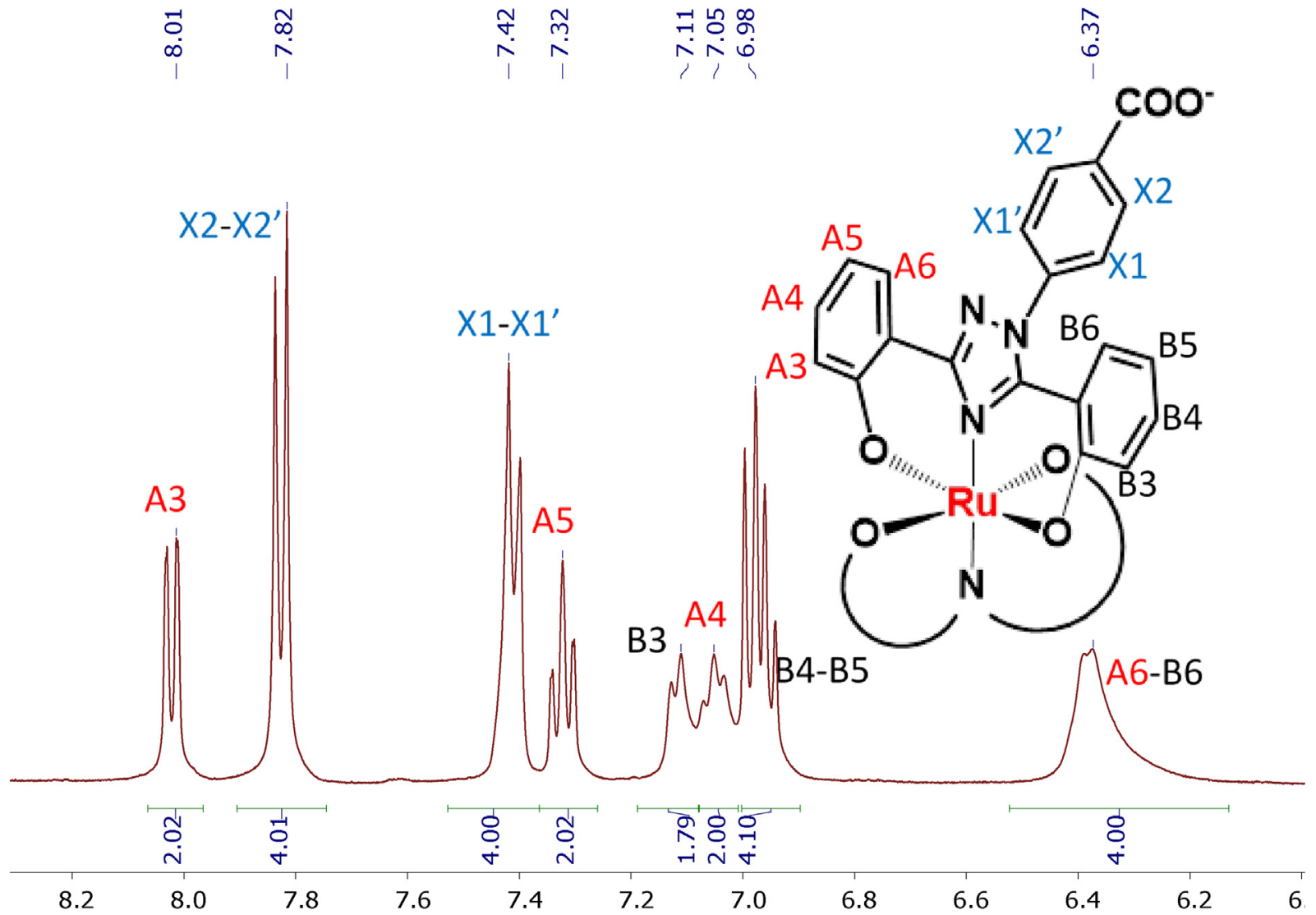

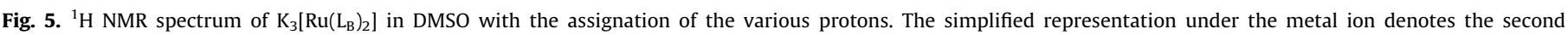
coordinating $\mathrm{L}_{\mathrm{B}}^{3-}$ ligand.

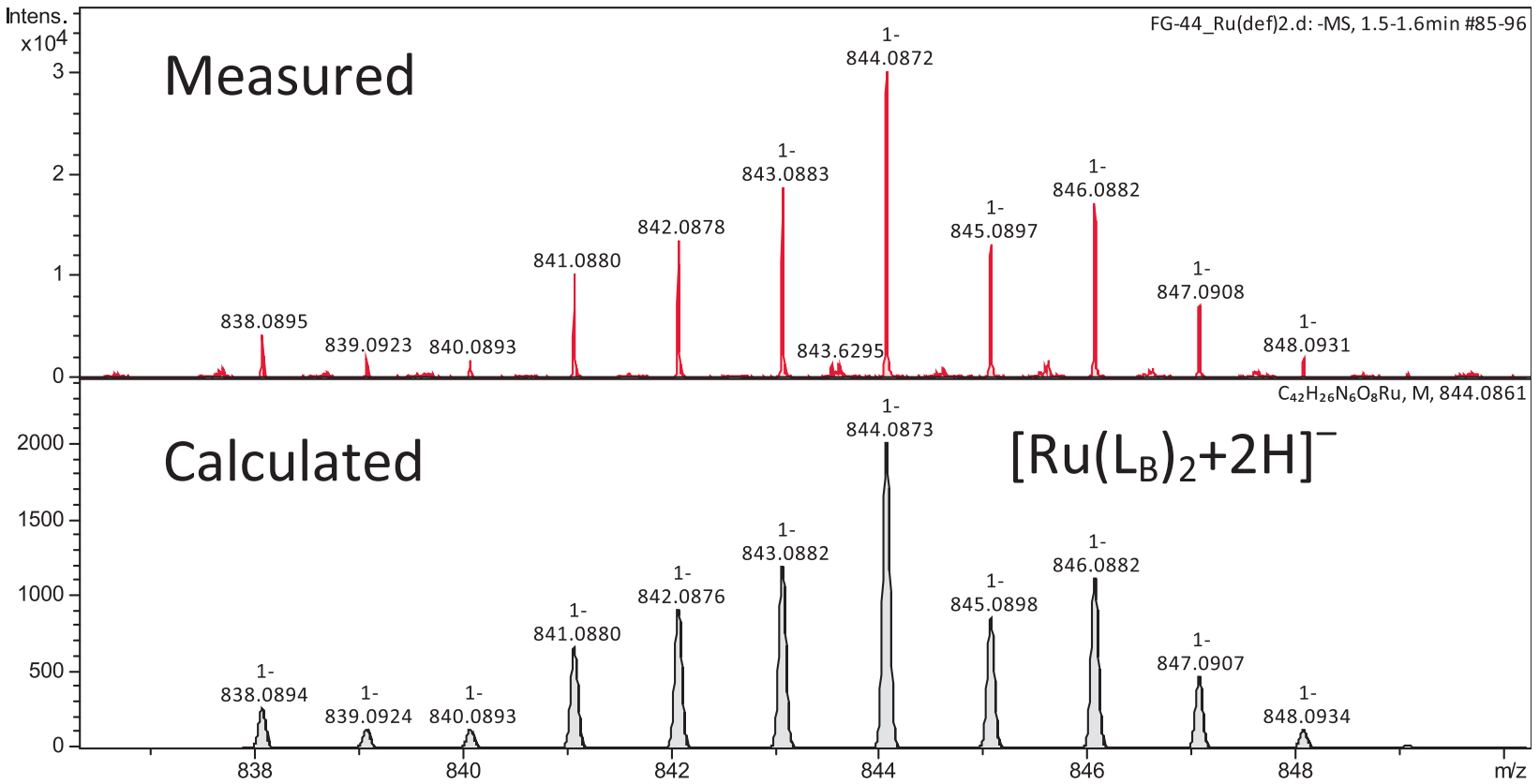

Fig. 6. Measured and calculated ESI-MS spectrum of $\left[\mathrm{Ru}\left(\mathrm{L}_{\mathrm{B}}\right)_{2}+2 \mathrm{H}\right]^{-}$ion in $\mathrm{MeOH}$.

and $\mathrm{H}_{3} \mathrm{~L}_{\mathrm{B}}$ using conc. $\mathrm{H}_{2} \mathrm{SO}_{4}$ at $130{ }^{\circ} \mathrm{C}$ for $3 \mathrm{hr}$. After recrystallization the products were characterized by various analytical techniques. The overlay of the ${ }^{1} \mathrm{H}$ NMR spectra of $\mathrm{H}_{3} \mathrm{~L}_{B}$ and $\mathrm{H}_{4} \mathrm{~L}_{\bar{D}}^{-}$ (Fig. S1) shows that for $\mathrm{H}_{4} \mathrm{~L}_{\mathrm{D}}^{-}$the number of aromatic hydrogens is ten which is consistent with the presence of two sulfonate groups in $\mathrm{H}_{4} \mathrm{~L}_{\mathrm{D}}^{-}$. Furthermore, COSY spectrum of $\mathrm{H}_{4} \mathrm{~L}_{\mathrm{D}}^{-}$(Fig. 2) reveals three sets of cross peaks belonging to the three spin systems of the rings of $\mathrm{H}_{4} \mathrm{~L}_{\mathrm{D}}^{-}$. The corresponding cross peaks of each 


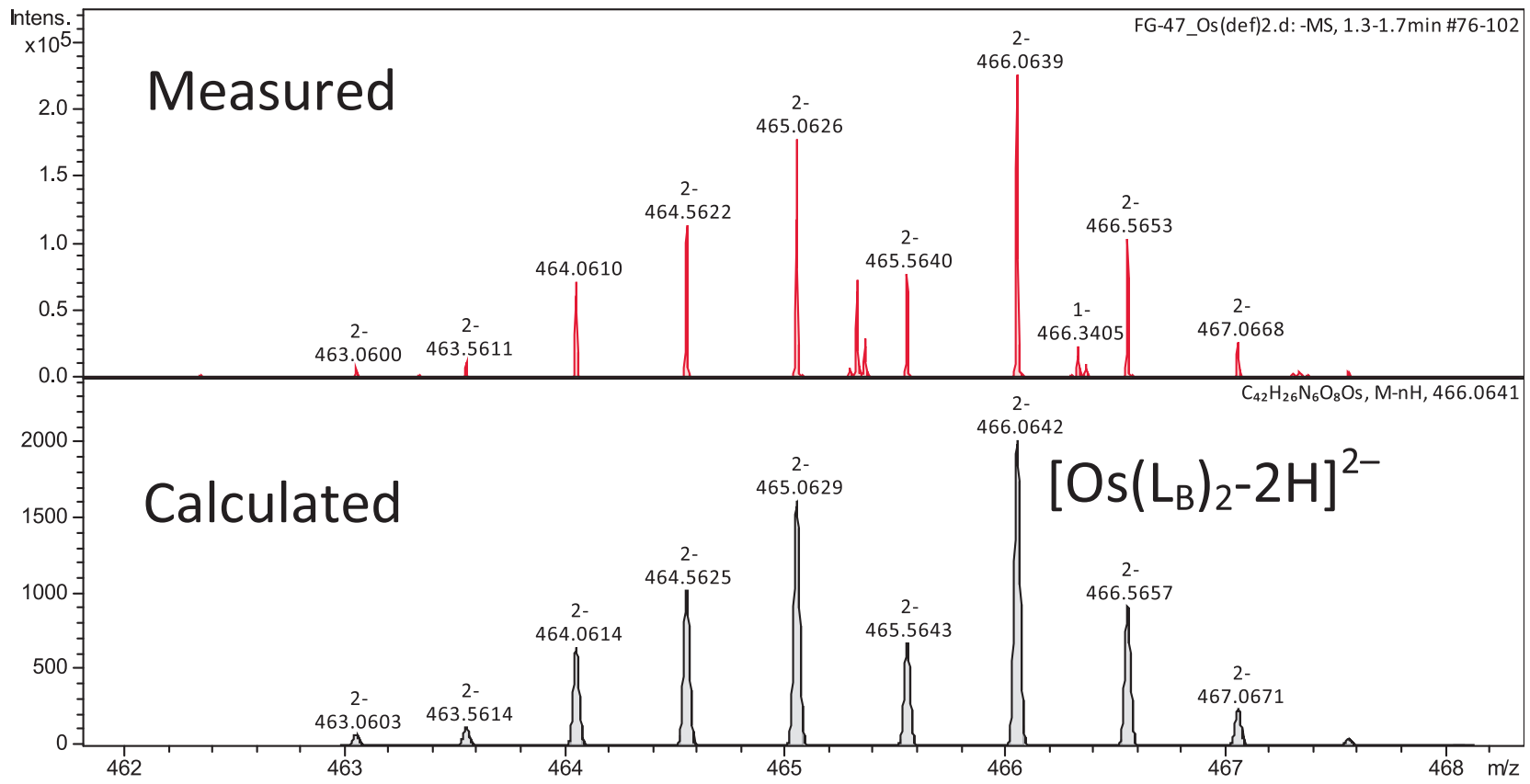

Fig. 7. Measured and calculated isotope patterns in the ESI-MS spectrum of $\left[\mathrm{Os}\left(\mathrm{L}_{\mathrm{B}}\right)_{2}-2 \mathrm{H}\right]^{2-}$ ion in $\mathrm{MeOH}$.

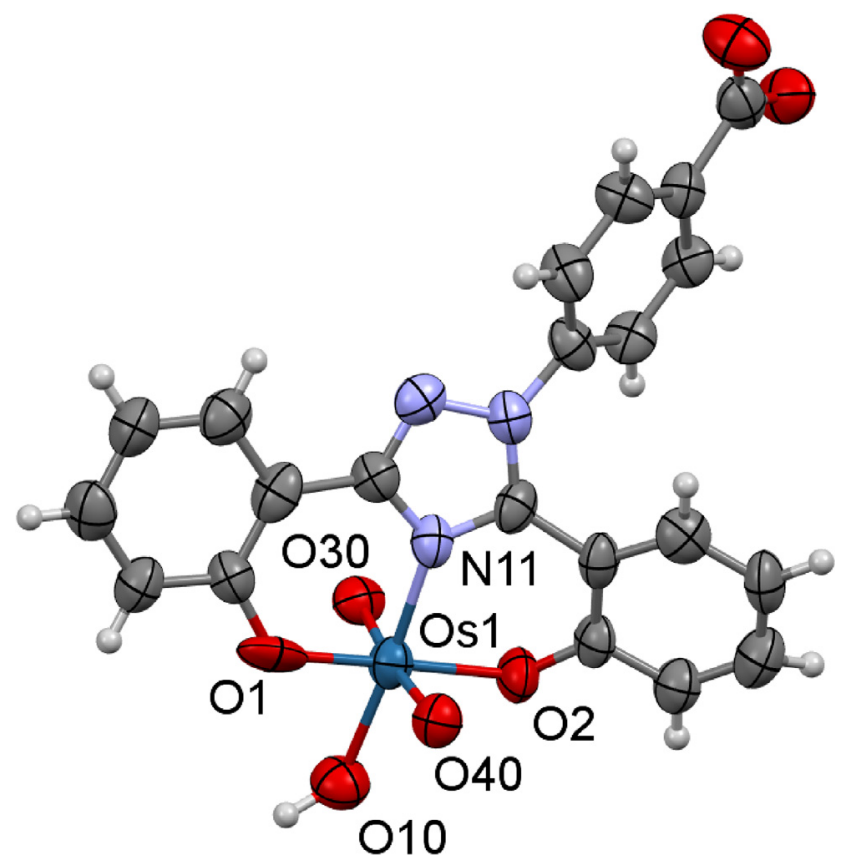

Fig. 8. ORTEP view of the $\left[\mathrm{Os}^{\mathrm{VI}} \mathrm{L}_{\mathrm{B}}(\mathrm{O})_{2} \mathrm{OH}\right]^{2-}$ anion. Thermal ellipsoids are shown at $50 \%$ probability level with partial numbering scheme. Selected bond lengths $(\AA)$ and angles $\left({ }^{\circ}\right)$ : Os(1)-O(1) 1.917(15), Os(1)-O(2) 2.057(11), Os(1)-N(11) 2.063(13), Os (1)-O(10) 2.103(11), Os(1)-O(30) 1.719(10), Os(1)-O(40) 1.716(11), O(30)-Os(1)-O (40) 172.4(5), O(1)-Os(1)-O(2) 178.8(4), N(11)-Os(1)-O(10) 176.2(5).

spin systems are indicated by the same color. The number of hydrogens on $A$ and $B$ rings being three while on $X$ ring being four clearly supports that the substitution took place at the $\mathrm{A}$ and $\mathrm{B}$ rings of $\mathrm{H}_{4} \mathrm{~L}_{\mathrm{D}}^{-}$.

To prove directly the molecular structure of the new ligands, single crystals of $\mathrm{NaH}_{3} \mathrm{~L}_{\mathrm{C}} \cdot 4 \mathrm{H}_{2} \mathrm{O}$ and $\mathrm{NaH}_{4} \mathrm{~L}_{\mathrm{D}} \cdot 3.25 \mathrm{H}_{2} \mathrm{O}$ were grown by slow evaporation of $\mathrm{NaCl}$ containing aqueous solutions of the products. X-ray diffraction studies also confirmed the presence of the sulfonate groups at the $\mathrm{A}$ and $\mathrm{B}$ rings in 5 and $5^{\prime}$ positions (Figs. 3 and 4) while other parts of the ligands remained unaffected upon sulfonation. Both of the solid state structures are polymeric and stabilized by ionic interactions between sodium cations and oxygen atoms of the sulfonate groups or solvent water molecules as well as by strong hydrogen bonds.

\subsection{Synthesis and characterization of the metal complexes}

Regarding the complex formation between the mentioned metal ions (all capable of forming octahedral complexes) and the ligands, formation of $1: 2$ species with $(\mathrm{O}, \mathrm{N}, \mathrm{O})$ tridentate coordination of the ligands is expected [8]. All the four ligands were tested for complex formation but the sulfonated derivatives $\mathrm{H}_{3} \mathrm{~L}_{\mathrm{C}}^{-}$and $\mathrm{H}_{4} \mathrm{~L}_{\mathrm{D}}^{-}$turned to be not suitable for the preparation of well characterized solid products. This is most likely due to the large overall negative charge of the ligands and complexes that are formed in the solvents used making difficult to crystallize the products. However, these latter ligands are suitable for solution equilibrium studies due to excellent water solubility while the position and properties of their chelate forming donor atoms are unaltered compared to $\mathrm{H}_{2} \mathrm{~L}_{\mathrm{A}}$ and $\mathrm{H}_{3} \mathrm{~L}_{\mathrm{B}}$ (vide infra).

Due to the poor water solubility of $\mathrm{H}_{2} \mathrm{~L}_{\mathrm{A}}$ and $\mathrm{H}_{3} \mathrm{~L}_{B}$ synthesis of the metal complexes was carried out in $\mathrm{MeOH}$. Taking into consideration the high tendency for most of the metal ions used in this study towards hydrolysis the synthetic routes were restricted to the application of $\mathrm{K}_{2} \mathrm{CO}_{3}$ or $\mathrm{Na}_{2} \mathrm{CO}_{3}$. These bases are poorly soluble in dried $\mathrm{MeOH}$ thus provide weakly alkaline conditions to avoid metal ion hydrolysis but enough to take the released protons from the ligands upon coordination to the metal ions. The excess of carbonate was more than tenfold to maintain the $\mathrm{pH}$ in the basic range.

For the synthesis of $\mathrm{K}\left[\mathrm{Ru}\left(\mathrm{L}_{\mathrm{B}}\right)_{2}\right], \mathrm{RuCl}_{3}$ and two fold excess of $\mathrm{H}_{3} \mathrm{~L}_{\mathrm{B}}$ were dissolved in $\mathrm{MeOH}$. In the presence of undissolved $\mathrm{K}_{2} \mathrm{CO}_{3}$ the reaction mixture became brown as the complex formed. The black solid isolated was subjected to various analytical techniques. ${ }^{1} \mathrm{H}$ NMR spectrum of the complex is consistent with the expected 1:2 stoichiometry (Fig. 5). 


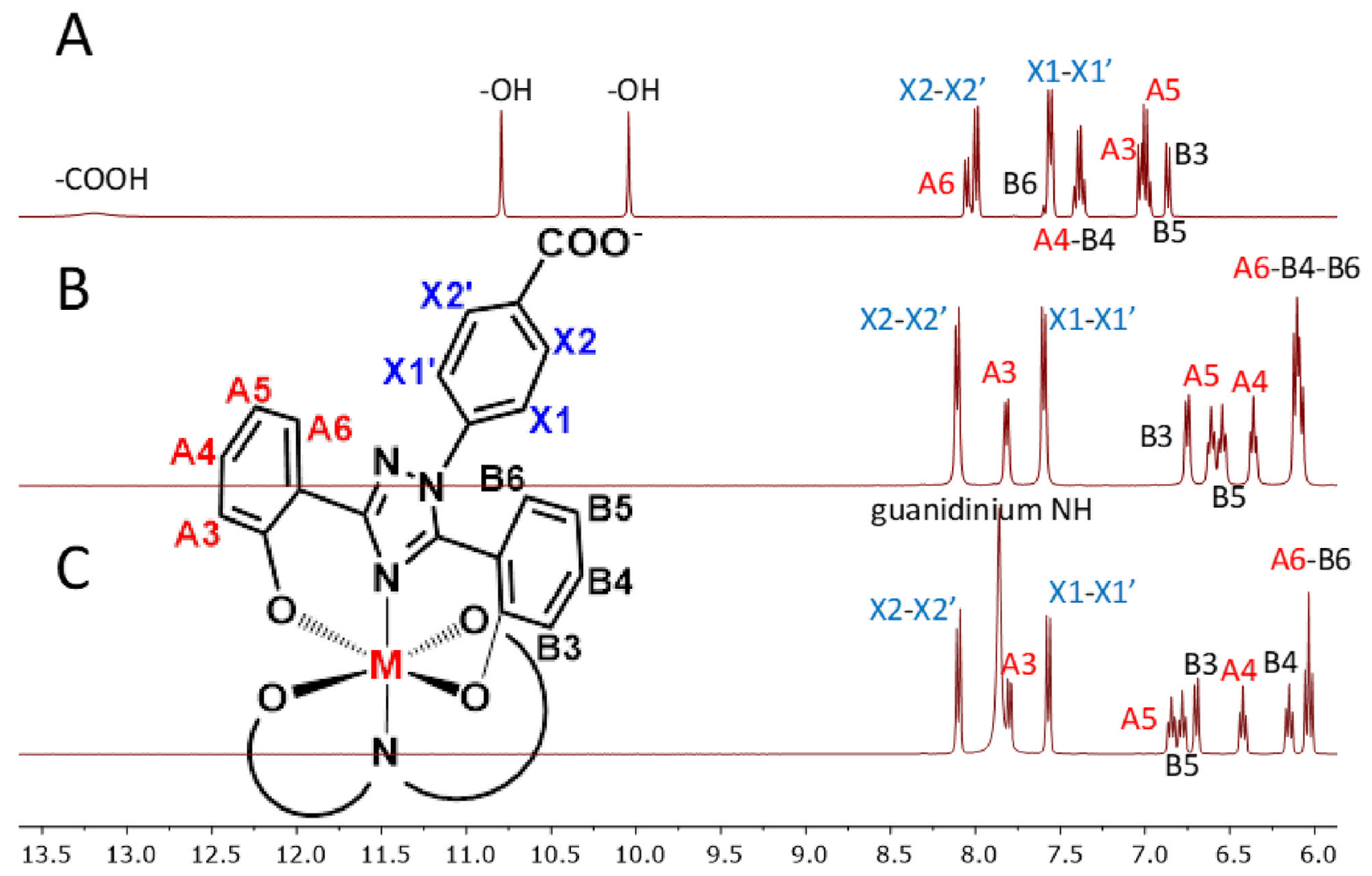

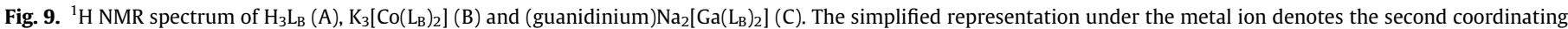
$\mathrm{L}_{\mathrm{B}}^{3-}$ ligand.

Due to the symmetrical tridentate coordination of the two ligands the sum of the signal integrals is 12 . Fig. 5 also indicates the roof effect of doublets of the protons at 7.82 and $7.42 \mathrm{ppm}$ located at the $\mathrm{X}$ ring. The $\mathrm{A} 3$ and $\mathrm{B} 3$ protons show up as doublets in the spectrum the latter having lower chemical shift due to higher shielding of the $B$ ring in the vicinity of the $X$ ring of the ligand. As it is expected the signals of the A4, A5 as well as B4, B5 protons are triplets; the appropriate couplings can clearly be seen in the COSY spectrum (Fig. S2). Due to the close vicinity to the coordination site of the ligand the signals of the A6 and B6 protons exhibit the highest upfield shifts and a strong pile-up.

The purity and identity of the ruthenium complex was also checked by HR ESI MS. As Fig. 6 reveals an excellent agreement of the isotope patterns for the observed and calculated MS spectra was found for the $\left[\mathrm{Ru}\left(\mathrm{L}_{\mathrm{B}}\right)_{2}+2 \mathrm{H}\right]^{-}$anion.

For the synthesis of the analogous Os complex the stable, octahedral $\left(\mathrm{NH}_{4}\right)_{2}\left[\mathrm{OsCl}_{6}\right]$ as precursor with $\mathrm{Os}(\mathrm{IV})$ was applied. $\left(\mathrm{NH}_{4}\right)_{2}\left[\mathrm{OsCl}_{6}\right]$ seemed to be a suitable starting material because the low solubility in almost every solvents also prevents hydrolysis and the chloride ions are likely exchangeable by the donor atoms of the chelating ligands. Due to the moderate reactivity and kinetic inertness of $\left(\mathrm{NH}_{4}\right)_{2} \mathrm{OsCl}_{6}$ extended reaction times were applied otherwise attempts to synthesize $\left[\mathrm{Os}\left(\mathrm{L}_{\mathrm{B}}\right)_{2}\right]^{n-}$ type complexes were carried out using very similar reaction conditions as for $K_{3}[\mathrm{Ru}$ $\left(\mathrm{L}_{\mathrm{B}}\right)_{2}$ ]. ESI-MS study of the isolated solids showed that the main component in the samples is the $\left[\mathrm{Os}\left(\mathrm{L}_{\mathrm{B}}\right)_{2}-2 \mathrm{H}\right]^{2-}$ ion (Fig. 7) besides other minor, metal containing ions as it is shown in the full spectrum in Fig. S3. Analysis of the NMR spectra of the obtained solids from different experiments, however, revealed that in every cases a complex reaction mixture was formed and a mixture of similar solids could only be isolated. The reason behind the strict differences in the stability of the ruthenium and the analogous osmium complex may be attributed to the lower oxidative stability of the low oxidation state Os compounds compared to those of the lighter congener. This hypothesis might be supported by the results of purification/crystallization experiments of the crude Os complex.

In recrystallization experiments, under aerobic conditions at room temperature, slow evaporation of the aqueous solution of the crude Os product afforded brown single crystals in a crystallization tube. Result of the SXRD analysis of the isolated solid is presented in Fig. 8 while the calculated key bond angles and distances are summarized in the caption to Fig. 8. The structure of the complex shows the expected octahedral geometry with one $\mathrm{L}_{\mathrm{B}}^{3-}$ ligand coordinating via a tridentate $(\mathrm{O}, \mathrm{N}, \mathrm{O})$ manner while the remaining coordination sites are occupied by two oxo groups trans to each other and one hydroxide ion. The presence of the oxo groups in the coordination sphere is supported by the short Os-O (30) of $1.719(10) \AA$ and $\mathrm{Os}-\mathrm{O}(40)$ of $1.716(11) \AA$ A bond distances falling into the range 1.71-1.74 $\AA$ characteristic for octahedral osmium complexes with an $\mathrm{Os}=\mathrm{O}$ double bond. The significantly longer Os-O(10) (2.103(11) Å) distance is indicative for an Os-O single bond based on search results in Cambridge Structural Database (Version 5.41, Update May 2020) [42]. The hydroxide ion of O (10) has a proton distributed over two sites with equal occupancy. This oxygen atom axially coordinated to osmium is also a bridging ligand for two potassium ions. Carboxylate oxygens also interact with the potassium ions what, together with solvent water molecules, result in a highly polymeric solid state structure stabilized by ionic interactions and hydrogen bonding networks (see Fig. S4). Furthermore, the +6 oxidation state of the metal ion is also supported by the ESI MS result shown in Fig. 7. Taken together, during the crystallization process the osmium get oxidized from its original +4 oxidation state and the most likely composition of the complex is $\mathrm{K}_{2}\left[\mathrm{Os}^{\mathrm{VI}} \mathrm{L}_{\mathrm{B}}(\mathrm{O})_{2} \mathrm{OH}\right]$. 


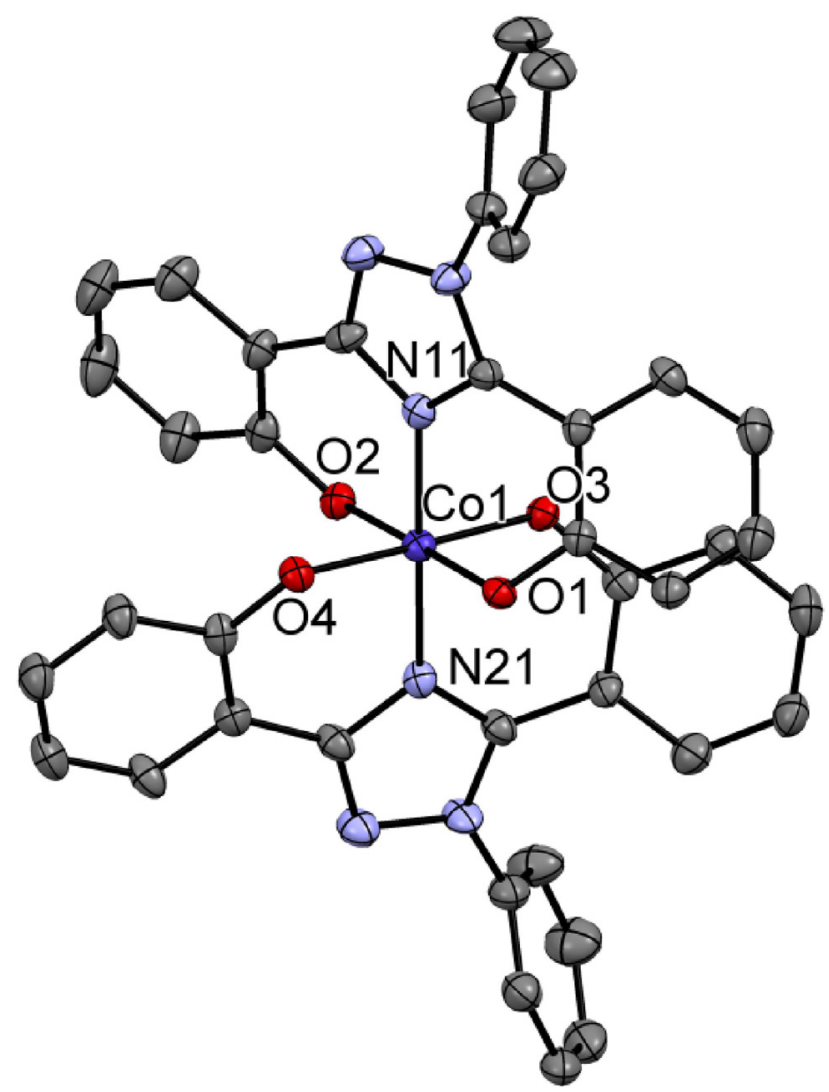

Fig. 10. ORTEP view of the anion of the $\mathrm{K}\left[\mathrm{Co}\left(\mathrm{L}_{\mathrm{A}}\right)_{2}\right] \cdot 2 \mathrm{Pr}^{\mathrm{i}} \mathrm{OH}$ complex. The counter ion and isopropyl alcohol molecules are omitted for clarity. Thermal ellipsoids are shown at $50 \%$ probability level with partial numbering scheme. Selected bond lengths $(\AA)$ and angles $\left({ }^{\circ}\right)$ : $\mathrm{Co}(1)-\mathrm{O}(1) 1.917(3), \mathrm{Co}(1)-\mathrm{O}(2) 1.885(3), \mathrm{Co}(1)-\mathrm{N}(11)$ 1.881(4), $\mathrm{Co}(1)-\mathrm{N}(21)$ 1.877(4), $\mathrm{Co}(1)-\mathrm{O}(3)$ 1.919(3), $\mathrm{Co}(1)-\mathrm{O}(4)$ 1.890(3), O(1)-Co (1) $-\mathrm{O}(2) 179.00(14), \mathrm{N}(11)-\mathrm{Co}(1)-\mathrm{N}(21)$ 179.40(17), O(3)-Co(1)-O(4) 178.89(15).
There are different synthetic routes to obtain $\mathrm{Co}$ (III) complexes including oxidation of $\mathrm{Co}(\mathrm{II})$ in the presence of the ligand by an adequate oxidizing agent or ligand exchange reactions using e.g. $\mathrm{Na}_{3}\left[\mathrm{Co}\left(\mathrm{CO}_{3}\right)_{3}\right]$ or $\left[\mathrm{Co}(\mathrm{acac})_{3}\right]$ precursors with exchangeable ligands. For the synthesis of the $\mathrm{L}_{\mathrm{A}}^{2-}$ and $\mathrm{L}_{\mathrm{B}}^{3-}$ complexes the latter cobalt source and $\mathrm{K}_{2} \mathrm{CO}_{3}$ as base were used. Beside the elemental analysis both NMR and ESI-MS studies (Figs. S5-S9) proved the identity and purity of the complexes $\mathrm{K}\left[\mathrm{Co}\left(\mathrm{L}_{\mathrm{A}}\right)_{2}\right]$ and $\mathrm{K}_{3}\left[\mathrm{Co}\left(\mathrm{L}_{\mathrm{B}}\right)_{2}\right]$. In particular, as a representative example, Fig. 9 compares the assigned ${ }^{1} \mathrm{H}$ NMR spectra of the free $\mathrm{H}_{3} \mathrm{~L}_{B}$ ligand (A) with that of $\mathrm{K}_{3}\left[\mathrm{Co}\left(\mathrm{L}_{\mathrm{B}}\right)_{2}\right](B)$. The assignation was carried out with the aid of the COSY spectrum (Fig. S7). The spectrum of $\mathrm{H}_{3} \mathrm{~L}_{\mathrm{B}}$ (Fig. 9A) acquired in DMSO shows the signals of the dissociable protons for the carboxylic and two phenolic groups too, while in the range $8.0-6.5 \mathrm{ppm}$ the aromatic protons of $\mathrm{H}_{3} \mathrm{~L}_{\mathrm{B}}$ resonate. The spectrum of $\mathrm{K}_{3}\left[\mathrm{Co}\left(\mathrm{L}_{\mathrm{B}}\right)_{2}\right]$ (B) highlights important differences compared to that of the ligand (Fig. 9A) because of the coordination. The assumed structure of the metal complex involves two identical, tridentately coordinating chelating ligands (the simplified representation under the metal ion in Fig. 9 denotes the second coordinating $\mathrm{L}_{\mathrm{B}}^{3-}$ ligand). This structure is supported by Fig. 9B as there is no indication for the doubling of the signals of the appropriate protons of the two coordinating ligands due to symmetry in the complex. Furthermore, the disappearance of the resonances belonging to the phenolic $\mathrm{OH}$ groups also in line with the tridentate coordination. Further comparison of spectra A and B reveals that the chemical shifts of $\mathrm{X} 2-\mathrm{X} 2$ ' and $\mathrm{X} 1-\mathrm{X} 1$ ' protons hardly change as they are far from the coordination sites unlike the resonances of the protons at the A and B rings of the ligands as these latter show upfield shift because of the increased electron density on the phenyl rings. On the contrary, signal of A3 protons shows downfield shift probably because it is located nearest to the coordination and farthest from the $\mathrm{X}$ ring of the ligand.

In order to obtain direct proof about the molecular structure of the $\mathrm{Co}(\mathrm{III})$ complexes, X-ray diffraction analysis of the single crystals of $\mathrm{K}\left[\mathrm{Co}\left(\mathrm{L}_{\mathrm{A}}\right)_{2}\right]$ obtained via slow diffusion of isopropanol into an

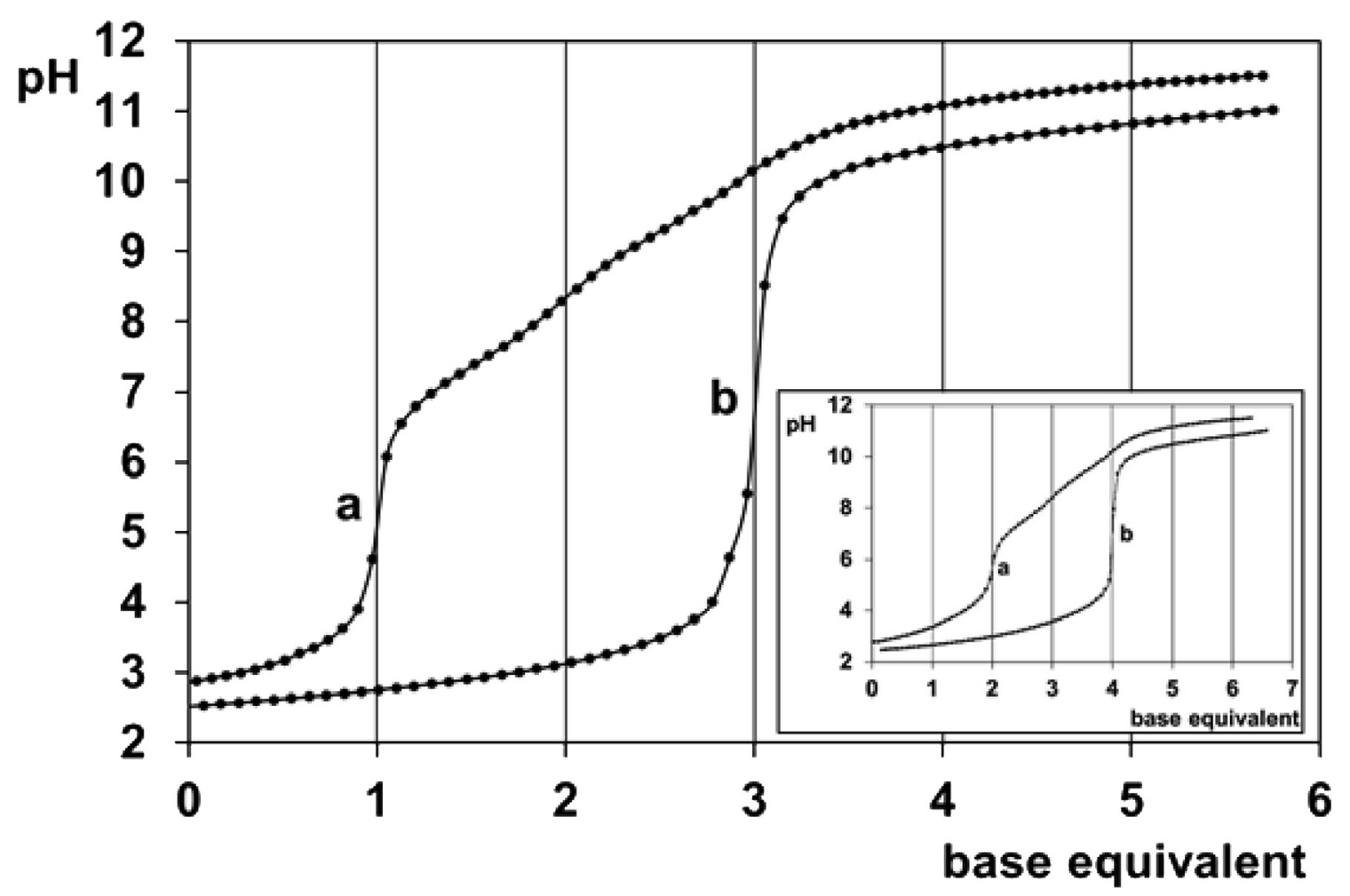

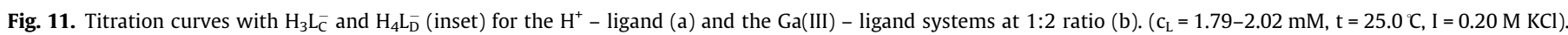


aqueous solution, was also carried out. As it is shown in Fig. 10, the unit cell contains the complex anion with two coordinating ligands around the $\mathrm{Co}(\mathrm{III})$ ion in the above expected tridentate manner. The calculated key bond length and angle values (summarized in the caption to Fig. 10) prove the very slightly distorted octahedral geometry of the complexes. The unit cell also contains one $\mathrm{K}^{+}$ion and two isopropanol molecules.

The synthesis of (guanidinium) $\mathrm{Na}_{2}\left[\mathrm{Ga}\left(\mathrm{L}_{\mathrm{B}}\right)_{2}\right]$ was slightly different from those of the previous complexes. Since the hydrolysis of $\mathrm{Ga}$ (III) is significant as low as $\mathrm{pH} \sim 3$ the adjustment of the $\mathrm{pH}$ during the synthesis was achieved via the continuous addition of small amounts of $\mathrm{Na}_{2} \mathrm{CO}_{3}$ to the reactants in a water-MeOH 1:4 solvent mixture (see Expt. part). Since the use of $\mathrm{Na}^{+}$as counter ion to obtain the desired complex in the solid form resulted in the cocrystallization of some inorganic impurities, guanidine nitrate [43] was used as a crystallizing agent. ESI-MS and ${ }^{1} \mathrm{H}$ NMR studies confirmed the purity, the expected 1:2 metal ion to ligand stoichiometry and the presence of one guanidinium cation in the obtained crystalline solid (see Figs. S10 and S11). In particular, the spectrum of (guanidinium) $\mathrm{Na}_{2}\left[\mathrm{Ga}\left(\mathrm{L}_{\mathrm{B}}\right)_{2}\right]$ (see Fig. 9C) is rather similar to the B spectrum belonging to the $\mathrm{Co}(\mathrm{III})$ complex with proven structure (vide supra). The signal of the guanidinium protons with an integral of $\sim 6$ can be seen at $7.6 \mathrm{ppm}$.

\subsection{Equilibrium studies in the $\mathrm{Ga}(\mathrm{III})-\mathrm{H}_{3} \mathrm{~L}_{\mathrm{C}}^{-}$And $-\mathrm{H}_{4} \mathrm{~L}_{\bar{D}}^{-}$Systems}

In order to estimate the fate of the administered metal complexes solution speciation studies on the appropriate metal ion-ligand system could provide with valuable information. Since the aqueous solubility of $\mathrm{H}_{2} \mathrm{~L}_{\mathrm{A}}$ and $\mathrm{H}_{3} \mathrm{~L}_{\mathrm{B}}$ is limited, their new disulfonated derivatives with excellent solubility, $\mathrm{H}_{4} \mathrm{~L}_{C}$ and $\mathrm{H}_{5} \mathrm{~L}_{\mathrm{D}}$, were used in solution equilibrium studies. For these latter ligands the $(\mathrm{O}, \mathrm{N}, \mathrm{O})$ donoratom set is unaltered compared to $\mathrm{H}_{2} \mathrm{~L}_{\mathrm{A}}$ and $\mathrm{H}_{3} \mathrm{~L}_{\mathrm{B}}$, respectively, thus the assumed coordination mode can be adopted to model them. Due to redox instability of the appropriate aquo species of osmium $\left(\left[\mathrm{Os}\left(\mathrm{H}_{2} \mathrm{O}\right)_{6}\right]^{3 / 4^{+}}\right)$and cobalt $\left(\left[\mathrm{Co}\left(\mathrm{H}_{2} \mathrm{O}\right)_{6}\right]^{3+}\right)$, and/or the unexplored, slow hydrolytic processes for ruthenium $\left(\left[\mathrm{Ru}\left(\mathrm{H}_{2} \mathrm{O}\right)_{6}\right]^{3+}\right)$ the solution equilibrium studies were restricted to the $\mathrm{Ga}(\mathrm{III})-\mathrm{H}_{4} \mathrm{~L}_{\mathrm{C}}$ and $-\mathrm{H}_{5} \mathrm{~L}_{\mathrm{D}}$ systems.

As representative examples titration curves for the two sulfonated ligands are presented in Fig. 11. Due to the high acidity of the sulfonic groups at the beginning of the titrations these are already deprotonated and three $\left(\mathrm{H}_{3} \mathrm{~L}_{\mathrm{C}}^{-}\right)$or four $\left(\mathrm{H}_{4} \mathrm{~L}_{\mathrm{D}}^{-}\right)$measurable deprotonation processes can be detected. Fig. 11 reveals that for $\mathrm{H}_{3} \mathrm{~L}_{\mathrm{C}}^{-}$one while for $\mathrm{H}_{4} \mathrm{~L}_{\mathrm{D}}^{-}$two equivalents of base is consumed until the inflexion point and these can be attributed to the proton loss of the triazolium units below $\mathrm{pH} 2.5$ for both ligands and to that of the carboxylic group below pH 5 for $\mathrm{H}_{3} \mathrm{~L}_{\mathrm{D}}^{2-}$. In both of the systems the two phenolic entities deprotonate in partly separated processes above the $\mathrm{pH}$ jump, in the basic $\mathrm{pH}$ range. The calculated protonation constants of the ligands are presented in Table 2. Comparison of the appropriate $\log K$ values of $\mathrm{L}_{\mathrm{C}}^{4-}$ and $\mathrm{L}_{\mathrm{D}}^{5-}$ (Table 2) with those of $\mathrm{L}_{\mathrm{B}}^{3-}\left(\log K_{\mathrm{COOH}}=3.7 ; \log K_{\mathrm{OH}(1)}=9.0 ; \log K_{\mathrm{OH}(2)}=10.6\right.$ [8] obtained in solvent mixture and calculated via extrapolation to pure aqueous medium) clearly indicates the electron withdrawing effect of the sulfonate groups located in the vicinity of the phenolic groups thus making them significantly more acidic in the new ligands of the present study.

Titration curves registered in the $\mathrm{Ga}(\mathrm{III})-\mathrm{H}_{3} \mathrm{~L}_{\mathrm{C}}^{-}$and $-\mathrm{H}_{4} \mathrm{~L}_{\mathrm{D}}^{-}$systems at $1: 1$ and $1: 2$ ratio (Fig. 11 ) reveal that there is already a significant complex formation between the ligands and the metal ion at the beginning of the titrations. For both of the $1: 1$ systems precipitation occurred at $\mathrm{pH} \sim 4.5$ most probably because of the intensive hydrolysis of the metal ion and formation of $\mathrm{Ga}(\mathrm{OH})_{3}$, therefore these titrations were terminated and data points below $\mathrm{pH} \sim 4$ were only used in the calculations. For the 1:2 samples
Table 2

Stepwise protonation constants ( $\log K$ ) of the ligands and overall stability constants $(\log \beta)$ of their $\mathrm{Ga}(\mathrm{III})$ complexes at $25.0^{\circ} \mathrm{C}$ and $\mathrm{I}=0.20 \mathrm{M} \mathrm{KCl}{ }^{*}$

\begin{tabular}{lll}
\hline & $\mathrm{L}_{\mathrm{C}}^{4-}$ & $\mathrm{L}_{\mathrm{D}}^{5-}$ \\
\hline $\log K_{\mathrm{HL}}$ & $9.23(2)$ & $9.25(1)$ \\
$\log K_{\mathrm{H} 2 \mathrm{~L}}$ & $7.31(3)$ & $7.38(2)$ \\
$\log K_{\mathrm{H} 3 \mathrm{~L}}$ & $1.36(3)$ & $3.74(2)$ \\
$\log K_{\mathrm{H} 4 \mathrm{~L}}$ & $<1$ & $1.24(8)$ \\
$\log K_{\mathrm{H} 5 \mathrm{~L}}$ & $<1$ & $<1$ \\
$\log K_{\mathrm{H} 6 \mathrm{~L}}$ & - & $<1$ \\
$\log \beta_{[\mathrm{GaLH} 2]}$ & - & $21.66(8)$ \\
$\log \beta_{[\mathrm{GaLH}]}$ & $20.03(3)$ & - \\
$\log \beta_{[\mathrm{GaL}]}$ & $17.56(5)$ & $17.64(4)$ \\
$\log \beta_{[\mathrm{GaL} 2 \mathrm{H}]}$ & $34.99(5)$ & $34.65(5)$ \\
$\log \beta_{[\mathrm{GaL} 2]}$ & $31.70(1)$ & $30.91(2)$ \\
$\log \beta_{[\mathrm{GaL} 2 \mathrm{H}-1]}$ & $20.4(1)$ & $20.02(8)$ \\
Fitting parameter (mL) & 0.00327 & 0.00543 \\
Number of fitted data & 120 & 94 \\
\hline
\end{tabular}

* $3 \sigma$ standard deviations are in parentheses, charges of the species are omitted. ${ }^{a}$ Fitting parameter is the average difference between the calculated and experimental titration curves expressed in the volume of the titrant.

(Fig. 11) the titrations were carried out in the range $2.0<\mathrm{pH}<11.0$. Comparison of the titration curves of the free ligands with those of the 1:2 samples indicates that in the presence of $\mathrm{Ga}$ (III) deprotonation of the phenolic groups takes places by $\mathrm{pH} \sim 5$ resulting in the formation of 1:2 complexes with high stability in both systems. Above $\mathrm{pH} \sim 9$, however, hydrolysis is detected suggesting the formation and presence of the water soluble $\left[\mathrm{Ga}(\mathrm{OH})_{4}\right]^{-}$. Evaluation of the titration curves with the aid of the PSEQUAD program [35] resulted in the models and sets of stability constants also summarized in Table 2.

As the calculated speciation curves for the $\mathrm{Ga}(\mathrm{III})-\mathrm{H}_{3} \mathrm{~L}_{\mathrm{C}}^{-}$system at $1: 2$ ratio show (Fig. S12) at $\mathrm{pH} 2$ the complexation starts with the formation of $\left[\mathrm{GaHL}_{\mathrm{C}}\right]$ in which the nitrogen atom of the triazole and one phenolate-O coordinate to the $\mathrm{Ga}$ (III) while the other phenolic $\mathrm{OH}$ is still protonated. Low $\mathrm{pK}_{\mathrm{GaHLC}}=20.07-17.60=2.47$ (Table 2) indicates the enhanced deprotonation of the second phenolic group yielding $\left[\mathrm{GaL}_{\mathrm{C}}\right]$ with tridentate coordination of the ligand. Parallel with this process coordination of a second ligand to $\left[\mathrm{GaL}_{\mathrm{C}}\right]^{-}$is detectable resulting in the subsequent formation of $\left[\mathrm{GaH}\left(\mathrm{L}_{\mathrm{C}}\right)_{2}\right]^{4-}$ and $\left[\mathrm{Ga}\left(\mathrm{L}_{\mathrm{C}}\right)_{2}\right]^{5-}$ the latter being the major species with $2 \times(\mathrm{O}, \mathrm{N}, \mathrm{O})$ coordination of the ligands over a wide $\mathrm{pH}$ range. As the titration curve (see Fig. 11) indicates above $\mathrm{pH} \sim 9$ the presence of further base consumption processes reveal the hydrolysis of $\left[\mathrm{Ga}\left(\mathrm{L}_{\mathrm{C}}\right)_{2}\right]^{5-}$ that can best be described with the formation of $\left[\mathrm{GaH}_{-1}\left(\mathrm{~L}_{\mathrm{C}}\right)_{2}\right]^{6-}$ as a mixed hydroxido species and that of [Ga $\left.(\mathrm{OH})_{4}\right]^{-}$.

For the other ligand $\left(\mathrm{H}_{4} \mathrm{~L}_{\mathrm{D}}^{-}\right)$with an extra carboxylic acid only slight differences in the complexation were found. The calculated speciation curves for the $\mathrm{Ga}(\mathrm{III})-\mathrm{H}_{4} \mathrm{~L}_{\bar{D}}$ system at $1: 2$ ratio show (Fig. 12) that at $\mathrm{pH} \sim 2$ the complexation starts with $\left[\mathrm{GaH}_{2} \mathrm{~L}_{\mathrm{D}}\right]$ in which the nitrogen atom of the triazole ring and one phenolateO coordinate to the $\mathrm{Ga}(\mathrm{III})$ while the other phenolic $\mathrm{OH}$ and the carboxylic groups are still protonated and may form an intramolecular hydrogen bonding with each other. The lack of measurable formation of $\left[\mathrm{Ga}\left(\mathrm{HL}_{\mathrm{D}}\right)\right]^{-}$indicates that the metal ion assisted deprotonation and coordination of the second phenolic group and that of the non-coordinating carboxylic group occurs parallel leading to the direct formation of $\left[\mathrm{Ga}\left(\mathrm{L}_{\mathrm{D}}\right)\right]^{2-}$. At an excess of ligand the complexation processes are similar as it was found for $\mathrm{H}_{3} \mathrm{~L}_{\mathrm{C}}^{-}$: a second ligand also binds to the metal ion resulting in the formation of $\left[\mathrm{GaH}\left(\mathrm{L}_{\mathrm{D}}\right)_{2}\right]^{6-},\left[\mathrm{Ga}\left(\mathrm{L}_{\mathrm{D}}\right)_{2}\right]^{7-}$ and $\left[\mathrm{GaH}_{-1}\left(\mathrm{~L}_{\mathrm{D}}\right)_{2}\right]^{8-}$, respectively on increasing the $\mathrm{pH}$. Comparison of the appropriate speciation curves in Fig. 12 (and in $\mathrm{S} 12$ for the $\mathrm{Ga}(\mathrm{III})-\mathrm{H}_{3} \mathrm{~L}_{\mathrm{C}}^{-} 1: 2$ system) calculated for $2 \mathrm{mM}$ and $1 \mathrm{M} \mathrm{Ga}(\mathrm{III})$ concentrations, respectively, also highlights that under biologically more relevant, low concentrations the hydrolysis becomes more significant. 

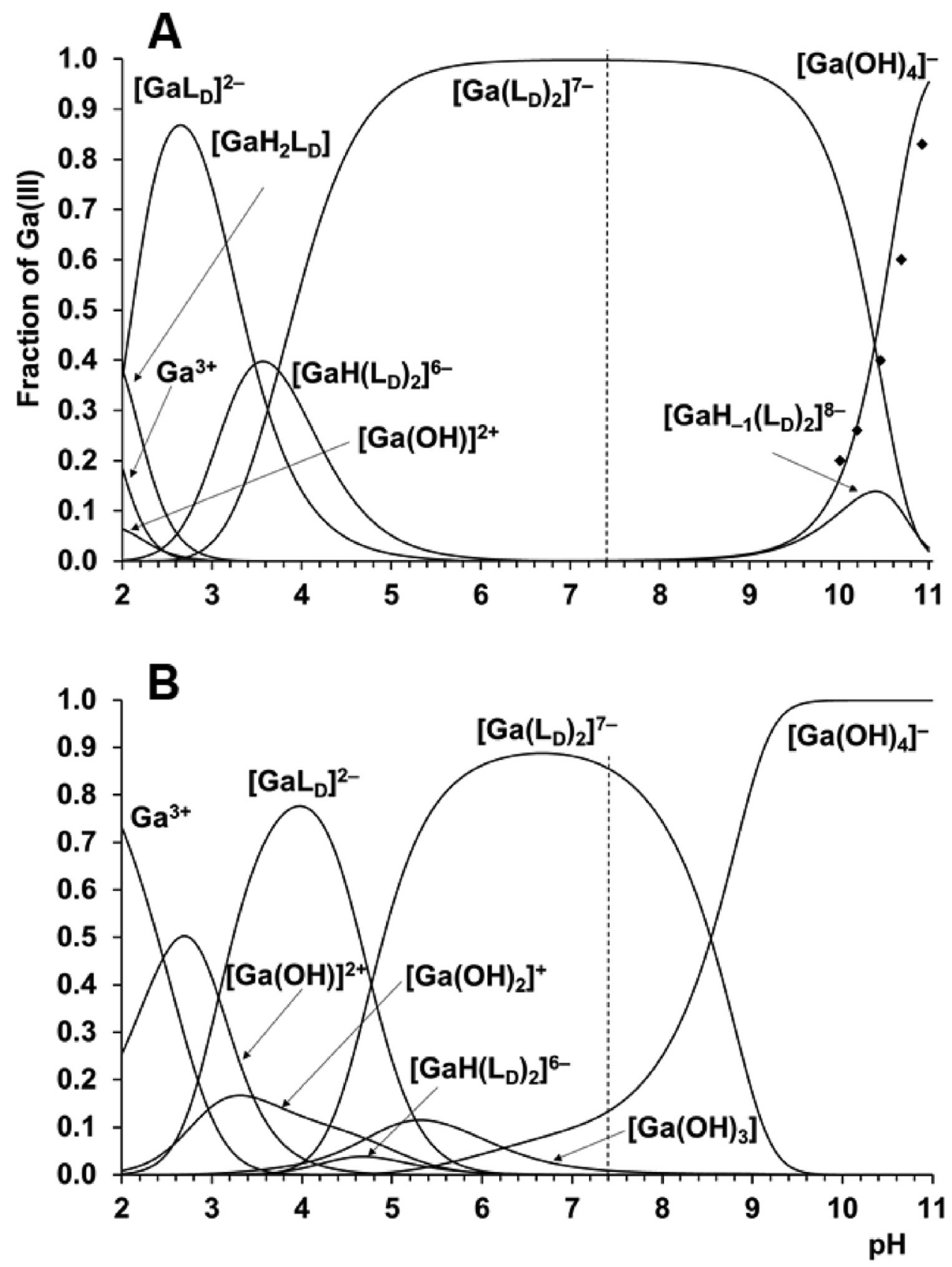

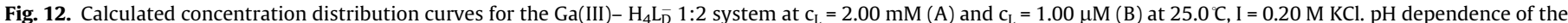
molar fraction of the uncomplexed $\mathrm{H}_{4} \mathrm{~L}_{\mathrm{D}}^{-}$from NMR data (indicating the amount of the hydrolysed metal ion) is marked by black squares in $\mathrm{A}$.

In order to obtain further information on the speciation and prove the correctness of the calculated distribution curves ${ }^{1} \mathrm{H}$ NMR experiments with WATERGATE sequence were also carried out. In Fig. 13 NMR signals of the fully deprotonated free $\mathrm{L}_{\mathrm{D}}^{5-}$ ligand together with the $\mathrm{pH}$ dependence of the resonances registered in the $\mathrm{Ga}(\mathrm{III})-\mathrm{H}_{4} \mathrm{~L}_{\mathrm{D}}^{-} 1: 2$ system are shown. The signals of the uncomplexed ligand in the $\mathrm{Ga}(\mathrm{III})$-containing samples are indicated in frames and are obviously proportional to the extent of hydrolysis of the 1:2 complex. Based on these signals and those belonging to the complexed ligand percentage of them can be calculated. Assuming that the percentage amount of the free $\mathrm{L}_{\mathrm{D}}^{5-}$ ligand is proportional with that of the uncomplexed metal ion indirect information can be obtained for the amount of $\left[\mathrm{Ga}(\mathrm{OH})_{4}\right]^{-}$in the range $7.0<\mathrm{pH}<11.0$ using individual samples. The obtained percentage values for the uncomplexed ligand in the $\mathrm{Ga}(\mathrm{III})-\mathrm{H}_{4} \mathrm{~L}_{\mathrm{D}}^{-} 1: 2$ system at various $\mathrm{pH}$ values shown in Fig. 13 are also depicted as black squares in Fig. 12A together with the speciation curves that are based on the stability constants determined from pH-potentiometry. As Fig. 12A clearly reveals there is a good fit between the NMR and potentiometric results supporting thus the correctness of the speciation model for the system.

\section{Conclusion}

Deferasirox and its derivatives are effective and important iron (III) chelators and this feature makes deferasirox widely used in the therapy of iron overload diseases. Since its pharmacological profile was studied in-depth and its long-term therapeutical use proven to be safe it can also serve as a ligand to construct chaperon com- 


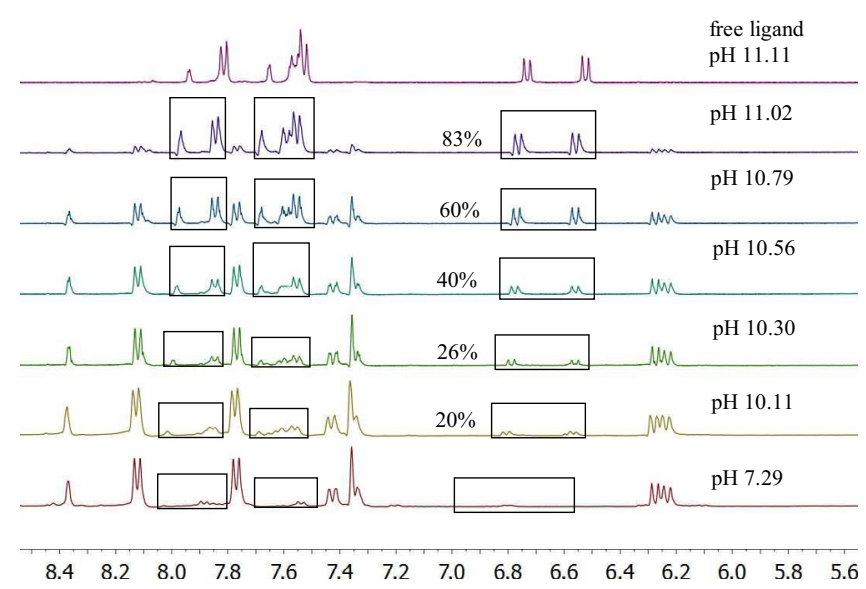

Fig. 13. ${ }^{1} \mathrm{H}$ NMR signals of the fully deprotonated free $\mathrm{L}_{\mathrm{D}}^{5-}$ ligand (top) and resonances of the $\mathrm{Ga}(\mathrm{III})-\mathrm{H}_{4} \mathrm{~L}_{\mathrm{D}}^{-} 1: 2$ system at various $\mathrm{pH}$ values. With their percentage values also shown, signals belonging to uncomplexed ligand are framed.

plexes with which metal ions with anticancer potential may selectively be delivered to the cancer cells. Furthermore, the strong iron sequestering capability may result in a further advantageous effect after the in vivo dissociation of the administered metal drugs: the shortage of iron(III) for the fast proliferating cancer cells hindering their physiological processes.

The results of the present study reveal that deferasirox or its decarboxy derivative are capable of forming stable $1: 2$ complexes in which the expected octahedral geometry is retained via the tridentate $(\mathrm{O}, \mathrm{N}, \mathrm{O})$ coordination of the ligands.

In order to obtain information about the likely fate of the administered metal complexes the solution behaviour of the $\mathrm{Ga}$ (III) system was also studied. (For the other metal ions in this study the very slow or unexplored hydrolytic processes hindered these investigations.) For the solution studies new disulfonate derivatives of deferasirox and decarboxy deferasirox with excellent water solubility were synthesized and characterized. Their complexation processes with $\mathrm{Ga}(\mathrm{III})$ revealed the formation of a 1:2 species with high stability at $\mathrm{pH}=7.4$ hindering the hydrolysis of the metal ion. Detailed biological studies may provide with further information on the anticancer potential of these new complexes and this work is planned to be carried out in the near future.

\section{CRediT authorship contribution statement}

Imre Nagy: Investigation, Visualization, Writing - original draft. Gergő Ferenczik: Investigation. Linda Bíró: Investigation. Etelka Farkas: Writing - review \& editing. Attila Cs. Bényei: Investigation. Péter Buglyó: Conceptualization, Supervision, Writing - review \& editing.

\section{Declaration of Competing Interest}

The authors declare that they have no known competing financial interests or personal relationships that could have appeared to influence the work reported in this paper.

\section{Acknowledgements}

The research was supported by the EU and co-financed by the European Regional Development Fund under the project GINOP2.3.2-15-2016-00008. The authors thank Mrs. Nikolett Nyujtó for participation in the synthetic work.

\section{Appendix A. Supplementary data}

CDC 2016327-2016330 contain the supplementary crystallographic data for $\mathrm{NaH}_{3} \mathrm{~L}_{\mathrm{C}} \cdot 4 \mathrm{H}_{2} \mathrm{O}, \mathrm{NaH}_{4} \mathrm{~L}_{\mathrm{D}} \cdot 3.25 \mathrm{H}_{2} \mathrm{O}, \mathrm{K}_{2}\left[\mathrm{OsL}_{\mathrm{B}}(\mathrm{O})_{2}\right.$ $(\mathrm{OH})] \cdot 4 \mathrm{H}_{2} \mathrm{O}$ and $\mathrm{K}\left[\mathrm{Co}\left(\mathrm{L}_{\mathrm{A}}\right)_{2}\right] \cdot 2 \mathrm{Pr}^{\mathrm{i}} \mathrm{OH}$, respectively. These data can be obtained free of charge via http://www.ccdc.cam.ac.uk/conts/ retrieving.html, or from the Cambridge Crystallographic Data Centre, 12 Union Road, Cambridge CB2 1EZ, UK; fax: (+44) 1223336-033; or e-mail: deposit@ccdc.cam.ac.uk. Supplementary data to this article can be found online at https://doi.org/10.1016/j. poly.2020.114780.

\section{References}

[1] H. Nick, Curr. Opin. Chem. Biol. 11 (2007) 419-423.

[2] M.D. Cappellini, Ther. Clin. Risk Manage. 3 (2) (2007) 291-299.

[3] M.D. Cappellini, P. Pattoneri, Ann. Rev. Med. 60 (2009) 25-38, https://doi.org/ 10.1146/annurev.med.60.041807.123243.

[4] R. Galanello, S. Campus, R. Origa, Expert Opin. Drug Metab. Toxicol. 8 (1) (2012) 123-134.

[5] R. Hider, Thalassemia Rep. 4 (2261) (2014) 19-27, https://doi.org/10.4081/ thal.2014.2261.

[6] P. Ricchi, A. Meloni, L. Pistoia, A. Spasiano, A. Spiga, M. Allò, M.R. Gamberini, R. Lisi, S. Campisi, A. Peluso, M. Missere, S. Renne, M. Mangione, V. Positano, A Pepe, Ann. Hematol. (2018), https://doi.org/10.1007/s00277-018-3397-3.

[7] U. Heinz, K. Hegetschweiler, P. Acklin, B. Faller, R. Lattmann, H.P. Schnebli, Angew. Chem. Int. Ed. 38 (1999) 2568-2570.

[8] S. Steinhauser, U. Heinz, M. Bartholomä, T. Weyhermüller, H. Nick, K. Hegetschweiler, Eur. J. Inorg. Chem. (2004) 41774192, https://doi.org/ 10.1002/ejic.200400363.

[9] S. Stucky, N.J. Koch, U. Heinz, K. Hegetschweiler, Chem. Papers 62 (4) (2008) 388-397, https://doi.org/10.2478/s11696-008-0043-X.

[10] F. Dahooee Balooch, S.J. Fatemi, M. Iranmanesh, Biometals 27 (2014) 89-95, https://doi.org/10.1007/s10534-013-9689-0.

[11] G. Crisponi, V.M. Nurchi, M. Crespo-Alonso, G. Sanna, M.A. Zoroddu, G. Alberti, R. Biesuz, PLoS One 10 (7) (2015), https://doi.org/10.1371/journal. pone.0133050 e0133050.

[12] S.V. Torti, F.M. Torti, Nat. Rev. Cancer 13 (2013) 342-355, https://doi.org/ $10.1038 /$ nrc3495.

[13] D.S. Kalinowski, D.R. Richardson, Pharmacol. Rev. 57 (2005) 547-583.

[14] Y. Yu, E. Gutierrez, Z. Kovacevic, F. Saletta, P. Obeidy, Y. Suryo Rahmanto, D.R. Richardson, Curr. Med. Chem., 19 (2012) 2689-2702.

[15] G.Y.L. Lui, P. Obeidy, S.J. Ford, C. Tselepis, D.M. Sharp, P.J. Jansson, D.S. Kalinowski, Z. Kovacevic, D.B. Lovejoy, D.R. Richardson, Mol. Pharmacol. 83 (2013) 179-190, https://doi.org/10.1124/mol.112.081893.

[16] J.-C. Lee, K.-C. Chiang, T.-H. Feng, Y.-J. Chen, S.-T. Chuang, K.-H. Tsui, L.-C. Chung, H.-H. Juang, Int. J. Mol. Sci. 17 (2016) 1435-1448, https://doi.org/ 10.3390/ijms17091435.

[17] M. Theerasilp, P. Chalermpanapun, K. Ponlamuangdee, D. Sukvanitvichai, N. Nasongkla, RSC Adv. 7 (2017) 11158-11169, https://doi.org/10.1039/ c6ra26669j.

[18] R.G. Kenny, C.J. Marmion, Chem. Rev. 119 (2019) 1058-1137.

[19] R.G. Kenny, C.J. Marmion, Enhancing the Therapeutic Potential of Platinumbased Anticancer Agents by Incorporating Clinically Approved Drugs as Ligands Ch. 1, The Royal Society of Chemistry, 2019, pp. 3-28.

[20] S.A. Loza-Rosas, A.M. Vázquez-Salgado, K.I. Rivero, L.J. Negrón, Y. Delgado, J.A. Benjamín-Rivera, A.L. Vázquez-Maldonado, T.B. Parks, C. Munet-Colón, A.D. Tinoco, Inorg. Chem. 56 (2017) 7788-7802, https://doi.org/10.1021/acs. inorgchem.7b00542.

[21] P.L. Parajdi-Losonczi, A.C. Bényei, É. Kováts, I. Timári, T.R. Muchova, J. Kasparkova, P. Buglyó, J. Inorg. Biochem. 160 (2016) 236-245.

[22] A.J. Godó, A.C. Bényei, B. Duff, D.A. Egan, P. Buglyó, RSC Adv. 2 (2012) 14861495.

[23] M. Kozsup, O. Dömötör, S. Nagy, E. Farkas, É.A. Enyedy, P. Buglyó, J. Inorg. Biochem. 204 (2020) 110963.

[24] I. Nagy, E. Farkas, J. Kasparkova, H. Kostrhunova, V. Brabec, P. Buglyó, J. Organomet. Chem. 916 (2020) 121265.

[25] S.M. Meier-Menches, C. Gerner, W. Berger, C.G. Hartinger, B.K. Keppler, Chem. Soc. Rev. 47 (2018) 909-928, https://doi.org/10.1039/c7cs00332c.

[26] I. Romero-Canelón, Ruthenium, Osmium and Iridium in the Fight Against Cancer Ch. 2, in: A. Casini, A. Vessières, S.M. Meier-Menches (Eds.), Metalbased Anticancer Agents, The Royal Society of Chemistry, 2019, pp. 31-61.

[27] M.A. Jakupec, B.K. Keppler, Curr. Top. Med. Chem. 4 (2004) 1575-1583.

[28] C.R. Chitambar, Fut. Med. Chem. 4 (2012) 1257-1272, https://doi.org/10.4155/ FMC.12.69.

[29] D.S. Padilha, Y.F. Santos, L.C. Giacomin, F.A.V. Castro, M.D. Pereira, A.B. Rocha, J. A.L.C. Resende, M. Scarpellini, Polyhedron 123 (2017) 480-489, https://doi. org/10.1016/j.poly.2016.12.020.

[30] M.C. Heffern, N. Yamamoto, R.J. Holbrook, A.L. Eckermann, T.J. Meade, Curr. Opin. Chem. Biol. 17 (2013) 189-196.

[31] G.S. Girolami, T.B. Rauchfuss, R.J. Angelici, Synthesis and Technique in Inorganic Chemistry, 3rd Ed., University Science Books, Sausalito, CA, 1999. 
[32] G. Gran, Acta Chem. Scand. 4 (1950) 559-577.

[33] H.M. Irving, M.G. Miles, L.D. Pettit, Anal. Chim. Acta 38 (1967) 475-488.

[34] P. Gans, A. Sabatini, A. Vacca, J. Chem. Soc., Dalton Trans. (1985) 1195-1200, https://doi.org/10.1039/DT9850001195.

[35] L. Zékány, I. Nagypál, in: Computational Methods for the Determination of Formation Constants, Springer US, Boston, MA, 1985, pp. 291-353, https://doi. org/10.1007/978-1-4684-4934-1_8.

[36] E. Farkas, E. Kozma, T. Kiss, I. Tóth, B. Kurzak, J. Chem. Soc., Dalton Trans. (1995) 477-481.
[37] A. Krezel, W. Bal, J. Inorg. Biochem. 98 (2004) 161-166.

[38] G. Sheldrick, Acta Crystallographica Section C 71 (2015) 3-8.

[39] S.P. Westrip, J. Appl. Crystallogr. 43 (2010) 920-925.

[40] A.L. Spek, Acta Crystallogr. A D65 (2009) 148-155.

[41] N. J. Koch, Ph.D. Thesis, Saarland University, Saarbrücken, 2011.

[42] C.R. Groom, I.J. Bruno, M.P. Lightfoot, S.C. Ward, Acta Crystallogr. A B72 (2016) $171-179$.

[43] A. Kathó, A.C. Bényei, F. Joó, M. Sági, Adv. Synth. Catal. 344 (2002) 278-282. 